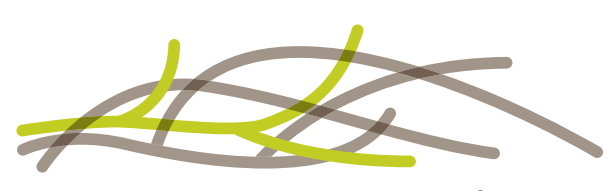

STEPScentre

Towards innovation democracy?

Participation, responsibility and

precaution in innovation governance

Andy Stirling

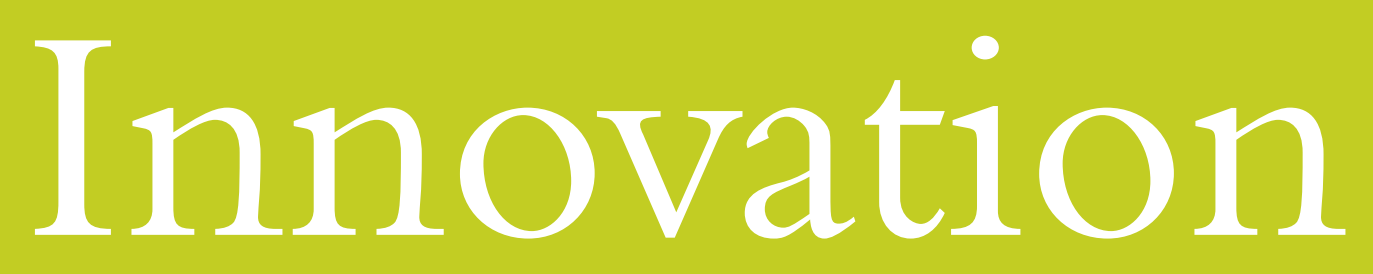




\section{Towards innovation democracy? \\ Participation, responsibility and precaution in innovation governance}

Innovation is about more than technological invention. It involves change of many kinds: cultural, organisational and behavioural as well as technological. So, in a world crying out for social justice and ecological care, innovation holds enormous progressive potential. Yet there are no guarantees that any particular realised innovation will necessarily be positive. Indeed, powerful forces 'close down' innovation in the directions favoured by the most privileged interests. So harnessing the positive transformative potential for innovation in any given area, is not about optimizing some single self-evidently progressive trajectory in a 'race to the future'. Instead, it is about collaboratively exploring diverse and uncertain pathways - in ways that deliberately balance the spurious effects of incumbent power. In other words, what is needed is a more realistic, rational and vibrant "innovation democracy.

\section{About the author}

Andy Stirling is co-director of the ESRC STEPS Centre and works on many other projects at SPRU - Science Policy Research Unit at the University of Sussex. He's served on advisory bodies for the EU on Energy Policy, Science in Society, Collaborative Research,

Sustainability and Science Governance; for the UK government on toxic substances, GM crops, public engagement and science advice; and working groups for the Royal Society, Nuffield Council and UN IHDP as well as boards for several academic journals and Greenpeace International. He's currently on the ESRC Research Committee.

\section{About the STEPS Centre}

Today's world is experiencing rapid social, technological and environmental change, yet poverty and inequality are growing. Linking environmental sustainability with poverty reduction and social justice, and making science and technology work for the poor, have become central challenges of our times. The STEPS Centre (Social, Technological and Environmental Pathways to Sustainability) is an interdisciplinary global research and policy engagement hub that unites development studies with science and technology studies. We are developing a new approach to understanding and action on sustainability and development in an era of unprecedented dynamic change. Our pathways approach aims to link new theory with practical solutions that create better livelihoods, health and social justice for poor and marginalised people. The STEPS Centre is based at the Institute of Development Studies and SPRU (Science Policy Research Unit) at the University of Sussex, with partners in Africa, Asia and Latin America. We are funded by the ESRC, the UK's largest funding agency for research and training relating to social and economic issues.

www.steps-centre.org.

Follow us on Twitter Castepscentre

Other titles in this series include:

Approach Pathways to sustainability: an overview of the STEPS Centre approach

1. Dynamics Dynamic Systems and the Challenge of Sustainability

2. Governance Understanding Governance: pathways to sustainability

3. Designs Empowering Designs: towards more progressive appraisal of sustainability

4. Agriculture Agri-Food System Dynamics: pathways to sustainability in an era of uncertainty

5. Health Health in a Dynamic World

6. Water Liquid Dynamics: challenges for sustainability in water and sanitation

For more STEPS Centre publications visit: www.steps-centre.org/publications 


\section{Towards innovation democracy?}

Participation, responsibility and precaution in the politics of science and technology

Andy Stirling

STEPS Working Paper 78 
Correct citation: Stirling, A. (2015) Towards innovation democracy? Participation, responsibility and precaution in the politics of science and technology, STEPS Working Paper 78, Brighton: STEPS Centre

First published in 2015

(C) STEPS 2015

Some rights reserved - see copyright license for details

ISBN: 978-1-78118-212-3

This is a fully referenced version of Chapter 4, pp. 49-62, in the Annual Report of the Government Chief Scientific Adviser 2014, Innovation: Managing Risk, Not Avoiding It. Evidence and Case Studies, London: Government Office of Science, https://www.gov.uk/government/uploads/system/uploads/attachment data/file/376505/14-1190binnovation-managing-risk-evidence.pdf

For further information please contact: STEPS Centre, University of Sussex, Brighton BN1 9RE

Tel: +44 (0) 1273915673; Email: steps-centre@ids.ac.uk; web: www.steps-centre.org

STEPS Centre publications are published under a Creative Commons Attribution - Non-Commercial No Derivative Works 3.0 UK: England \& Wales Licence (http://creativecommons.org/licenses/by-nc$\mathrm{nd} / 3.0 /$ legalcode)

Attribution: You must attribute the work in the manner specified by the author or licensor.

Non-commercial: You may not use this work for commercial purposes.

No Derivative Works: You may not alter, transfer, or build on this work.

Users are welcome to copy, distribute, display, translate or perform this work without written permission subject to the conditions set out in the Creative Commons licence. For any reuse or distribution, you must make clear to others the licence terms of this work. If you use the work, we ask that you reference the STEPS Centre website (www.steps-centre.org) and send a copy of the work or a link to its use online to the following address for our archive: STEPS Centre, University of Sussex, Brighton BN1 9RE, UK (steps-centre@ids.ac.uk).

\section{cc)creative}




\section{Contents}

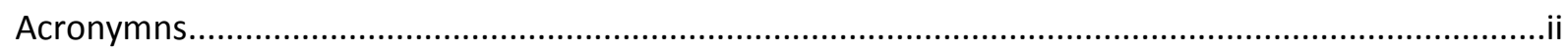

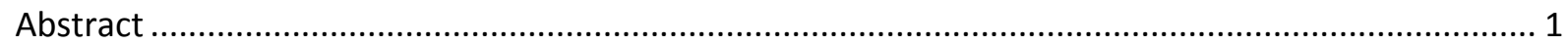

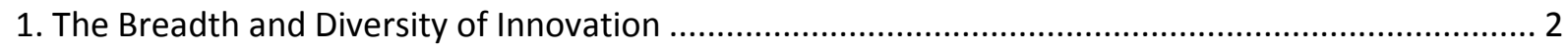

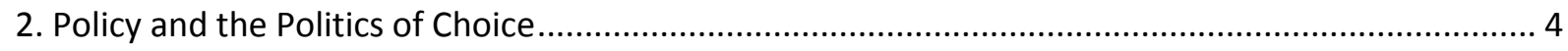

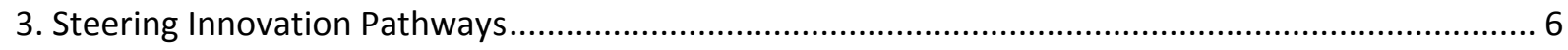

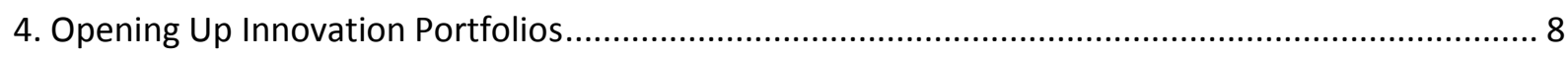

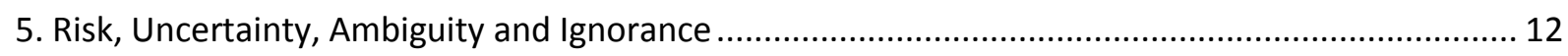

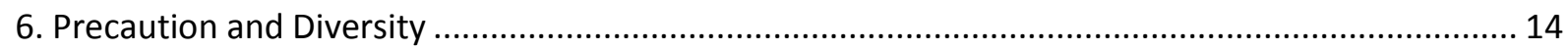

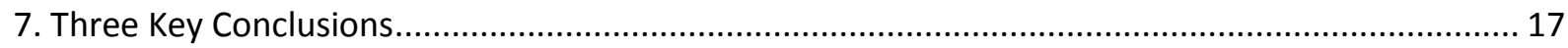

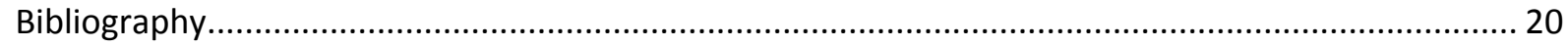




\section{Acronymns}

BSE

CFC

ECF

EEA

EPSRC

ERAB

EREC

ESRC

IPCC

IRGC

IRRI

OECD

ONR

CoRWM

GM

NBER

PCCRARM

PwC

RS

RAE

SPRU

TSB

UNEP

WBCSD

WBGU

WHO

WWF
Bovine Spongiform Encephalopathy

Chlorofluorocarbon

European Climate Foundation

European Environment Agency

Engineering and Physical Sciences Research Council

European Research Area Board

European Renewable Energey Council

Economic and Social Research Council

Intergovernmental Panel on Climate Change

International Risk Governance Council

International Rice Research Institute

Organisation for Economic Cooperation and Development

Office for Nucear Regulation

Committee on Radioactive Waste Management

Genetic Modification

National Bureau of Economic Research

Presidential/Congressional Commission on Risk Assessment and Risk Management

PricewaterhouseCoopers

Royal Society

Royal Academy of Engineering

Science Policy Research Unit

Technology Strategy Board

United Nations Environment Program

World Business Council for Sustainable Development

German Advisory Council on Global Change

World Health Organization

World Wildlife Fund 


\begin{abstract}
Innovation is about more than technological invention. It involves change of many kinds: cultural, organisational and behavioural as well as technological. So, in a world crying out for social justice and ecological care, innovation holds enormous progressive potential. Yet there are no guarantees that any particular realised innovation will necessarily be positive. Indeed, powerful forces 'close down' innovation in the directions favoured by the most privileged interests. So harnessing the positive transformative potential for innovation in any given area, is not about optimizing some single selfevidently progressive trajectory in a 'race to the future'. Instead, it is about collaboratively exploring diverse and uncertain pathways - in ways that deliberately balance the spurious effects of incumbent power. In other words, what are needed are more realistic, rational and vibrant 'innovation democracies'.
\end{abstract}

Yet conventional innovation policy and regulation tend simply to assume that whatever products or technologies are most energetically advanced, are in some way self-evidently beneficial. Scrutiny tends to be through narrow forms of quantitative 'risk assessment', focusing only on particular direct risks and asking merely whether they are 'tolerable' - often at a time too late for significant change. Technologies are typically privileged over other innovations. Attention is directed only in circumscribed ways at the pace of innovation The result is a serious neglect for the crucial issue of the direction of innovation in any given area - and increased vulnerability to various kinds of 'lock in'.

These patterns show up across all sectors. Beyond genetically modified (GM) crops, for example, there exist many other innovations for improving global food sustainability. But the relatively low potential for narrow commercial benefits often leave many promising options seriously neglected. With uncertainties side-lined or interpreted in expedient ways, even scientific evidence itself can carry the imprint of vested interests. And official statistics often conceal the extent to which patterns of support are concentrated in favour of particular innovation pathways. Yet these effects of power remain under-acknowledged in policy making. Policy is stated simply as 'pro-innovation' - as if this were a purely technical matter and always self-evidently good, rather than politically contestable.

To address these challenges, innovation policy should more explicitly and transparently acknowledge the inherently political nature of the interests and motivations driving contending possible pathways. Here, this paper explores the potential for three emerging bodies of practice, relevant across all areas: participation, responsibility and precaution. Each involves a range of practical methods, catalysing and reinforcing new institutional forms. Due to its efficacy in resisting political bias, precaution is a subject of particular misunderstanding and mischief. Among other qualities, this offers a crucial guard against the error of treating the absence of evidence of harm as evidence of absence of harm - and highlights the importance of wider human and environmental values.

Together, qualities of participation, responsibility and precaution help 'open up' scrutiny and accountability beyond anticipated consequences alone, to also interrogate the driving purposes of innovation. They allow societies to exercise agency not only over the rate and riskiness of innovation, but also over its direction. And they offer means to enable hitherto more distributed and marginal forms of innovation - which presently manage only rarely (like renewable energy or ecological farming) to struggle to major global scale. Together, these qualities celebrate that innovation is not a matter for fear-driven technical imperatives, but requires a democratic politics of contending hopes. 


\section{The Breadth and Diversity of Innovation}

Innovation is not just about technological inventions. It encompasses all the many ways of furthering human wellbeing. This includes improved production and use of goods or services in firms and other organisations (BIS 2011a). But it also includes new practices and relations in communities, households and the workplace (OECD 2010). Advanced science and technological research can help drive and enable innovation (Foresight Horizon Scanning Centre 2012). Yet many other new forms of knowledge and action are also important (NESTA 2006). Innovation can be created and guided by social venturing (Murray et al. 2009) and mobilisation (Murray et al. 2009) as much as commercial entrepreneurialism (TSB 2011). So grassroots movements (Smith et al. 2013), civil society (Bound and Thornton 2012), creative arts (ERAB 2012), and wider culture (Malhotra et al. 2009) feature alongside small business, service industries (CEC 2012) and the public sector (Harris and Albury 2009) in being as important for innovation as universities, research labs and high-tech companies.

Of course, there are no guarantees that any particular innovation in any of these areas will necessarily be positive. To take extreme examples that most may agree on, new forms of torture (Rejali 2007), financial fraud (Piketty 2014) or weapons of mass destruction (Peoples 2009; Cimbala 2005; Cirincione 2007; McLeish and Nightingale 2007; Rogers 2001; Yanarella 2002) are all active areas for innovation that might be judged to be generally negative. For other kinds of innovation, the picture is varyingly ambiguous. But it is rare that any given innovation is entirely, unconditionally or self-evidently positive (Tenner 1999). And judgements are always relative. So, the unqualified claim in the current British Government slogan, 'innovation is Great... Britain' (BIS n.d.) is not automatically true. Like other prevailing high-level talk of 'pro-innovation' policy - for instance, around the European Union's 'Innovation Union' strategy (European Commission 2009; CEC 2006; Eurobarometer 2005) - this misses the crucial point that the most important queries are about 'which innovation?' Whether or not any given innovation is preferable on balance to alternatives - let alone unreservedly 'good', still less "great" - is not just a technical issue. It is also a fundamentally political question. This means that even quite detailed aspects of innovation policy are legitimate matters for democracy (Sclove 1995; Winner 1992; Jasanoff 1996; Abraham and Sheppard 1997; Borgmann 1988; Shrader-Frechette 1992; Hippel 2005).

In these widest of senses, however, well-conceived innovations can undoubtedly offer important aids not only to economic productivity (Malerba and Brusoni 2007), but also to enhancing many kinds of human flourishing or the public good (CEC 2009). And this need not be a bone of contention, even under the most critical views (Lightman et al. 2003). The more ambitious the aspirations to progressive social change, the greater the need for broad, diverse (and carefully scrutinised) kinds of innovation (Steward 2008; Scrase et al. 2009). An example lies in the imperatives for transformations towards a more Sustainable (WBCSD 2010), equitable, healthy and peaceful world. Whatever forms these possible futures are held to take, they require radical kinds of innovation in the widest of senses (Stirling 2014a).

Some innovation opportunities can be effectively addressed by well-governed fair and efficient markets (OECD 2002). So, one important role for innovation policy lies in helping to foster commercial innovation in the public interest (OECD 2005). But not all benefits, risks or impacts are restricted to those private actors typically most directly involved in steering business innovation (Anon 2010). Established understandings, motivations and incentives driving the most powerful market actors, often fail fully to prioritise wider relevant social values and interests (Wyatt et al. 2000). In areas like health, agriculture, energy, environment, water, mobility, security, waste and housing, many of the least privileged (most vulnerable) people around the world are 
disproportionately excluded from conventional global patterns of innovation (STEPS 2010). Nor, as we shall see below, are many important forms of uncertainty and ambiguity always fully or appropriately addressed by relatively narrow market-based signals or official statistics (IRGC 2006).

Depending on the context, then, market processes alone do not necessarily drive the best orientations for the kinds of innovation that are most needed from broader social viewpoints. This is true both across different domains of policy as well as within any given sector. For instance, the single largest area for public expenditure on research and innovation - in the UK as worldwide - is military (OECD 2013) (Alic 2007). Innovation towards less violent means for conflict resolution are relatively neglected (Parkinson et al. 2013; Kaldor et al. 2004; Kaldor 2007). Likewise, the most strongly-pursued energy options are those that offer greatest returns on established infrastructures and supply chains, rather than new distributed forms of renewable power or energy services (Alic 2009; Popp and Newell 2009; Unruh 2000; Unruh 2002). For its part, biomedical research tends to focus more on health disorders of the rich than the poor, and on therapeutics rather than prevention (WHO 2002). This is especially so in speculative (but potentially lucrative) new areas like 'human enhancement' and 'life extension' (Miller and Wilsdon 2006; Lilley 2013; Nuffield Council 2012), with the Royal Society raising particular questions about patterns of prioritisation in neuroscience (Anon 2011). Consequently, there are important roles for public policy in helping to prioritise across sectors, as well as encourage and support appropriate scales and directions for innovation within particular areas. And (as we shall see later), public policy is also crucial in helping to address the many uncertainties and ambiguities - by promoting greater analysis, deliberation and political accountability (Hall and Rosenberg 2010).

In nurturing these qualities, public policy can also fulfil other significant roles. Alongside higher education, business and civil society, government policy can do much to promote the knowledges, capabilities and environments that best facilitate socially effective innovation (Mazzucato 2013). So, the more demanding the challenges for innovation (like poverty, ill health or environmental damage), the greater becomes the importance of effective policy (Owen et al. 2013; Jackson 2009). These challenges of innovation policy go well beyond simplistic notions of governments trying to 'pick winners' (Cable 2011; Scrase et al. 2010). In any case, imperfect or self-serving foresight does not exclusively afflict the public sector, but also applies to powerful market actors (Scrase and Mackerron 2009). Though manifest differently, essentially similar degrees of uncertainty, intractability and deficiency are equally experienced in government, business and civil society (Renn 2008). Instead then, the central challenge in innovation policy is about helping to harness the differences (Page 2007). This is about culturing the most fruitfully cross-fertilising conditions across society as a whole, for collectively seeding and selecting across many alternative possibilities and together nurturing the most potentially fruitful (Stirling 2014a). This involves collaboratively deliberating, negotiating and constructing what 'winning' even means, not just how best to achieve it. These are the questions on which this paper will focus. 


\section{Policy and the Politics of Choice}

The most important (but neglected (NESTA 2011)) issue here, is that innovation of all kinds in any given area is not a one-track race to the future (Broers 2005). Instead, it is about social choices across a variety of continually branching alternative pathways for change (Dosi 2000). In this sense, innovation is more like an evolutionary process than a race (Nelson and Winter 1982; Arthur 2009). It is as much about exploring a space of different possibilities, as optimising any one (Frenken 2004; Saviotti and Frenken 2008; Frenken et al. 1999). As already mentioned, it is rarely self-evident - and often hotly contested - what should count as the most 'desirable' directions for discovery. This is true, for instance, of particular domains like Sustainable agriculture, zero carbon energy services or clinical and preventive responses to improving public health. In all these areas, there unfold many radically contrasting alternative pathways for innovation. Two of the most pervasively important qualities in choosing which pathways to prioritise, are therefore: (i) attending fairly to a diversity of possible directions and strategies (Andy Stirling 2007a); and (ii) including a plurality of perspectives in appraising any one (Rescher 1993; O'Neill 1993; Bohmann 1996).

Consequently, it is not only important that innovation be efficient and competitive in any particular direction. It is also crucial equally for economic and wider social wellbeing, that the directions that are prioritised for innovation, are as robustly deliberated, accountable and legitimate as possible (Stirling 2010). An economy that fails to do this, exposes itself to the risk that it will become committed to inferior innovation pathways, that other more responsibly and responsively steered economies may avoid. In other words, innovation may 'go forward' quickly, but in the wrong directions.

History presents plenty of examples of innovation trajectories that later proved to be misguided. For instance involving asbestos, benzene, thalidomide, dioxins, lead in petrol, tobacco, many pesticides, mercury, chlorine and endocrine-disrupting compounds, as well as chlorofluorocarbons, high sulphur fuels and fossil fuels in general (EEA 2013; Harremoës et al. 2000). In all these and many other cases, delayed recognition of adverse effects incurred not only serious environmental or health impacts, but massive expense and reductions in competitiveness for firms and economies persisting in the wrong path (Porter and Linde 1995; Wagner 2003). Innovations reinforcing fossil fuel energy strategies (Scrase et al. 2010), such as hydraulic fracturing (Royal Society and Royal Academy of Engineering 2012), arguably offer a contemporary prospective example. And similar dilemmas are presented by the otherwise exciting new possibilities of nanotechnology (Royal Society 2004), both internally within this field and externally with respect to alternative ways to address the same priority social needs (Kearnes and Rip 2009).

The key conundrum here, is that each alternative innovation pathway in any given area, such as food, energy, health or security, will typically display contrasting pros and cons under contending perspectives. Animated differences emerge, for instance, around infrastructures for urban automobiles or cycling (Schiller et al. 2010), nuclear power or renewable energy (Ivan Scrase and Mackerron 2009) and violent or peaceful approaches to national security (Kaldor 2007; North 2004). Each involves different innovation trajectories. Competing pathways will also routinely differ in their social distributions of benefits and harms, winners and losers. And, in any view, the whole picture is further obscured by many deep unknowns. Crucially, a decision not to innovate will also present its own mix of pros, cons and uncertainties. Innovating in any particular direction will, for instance through foregone resources and opportunity costs, typically diminish innovation in others. Whether deliberate or inadvertent, each direction for innovation is a social choice involving issues of uncertainty, legitimacy and accountability as well as competitiveness. 
It is important to acknowledge these complexities of choice, because innovation debates in particular areas often become quite simplistic and polarised. For instance, innovation in fields like food, health, energy or warfare is frequently discussed as if it were a one-track race (Broers 2005), rather than an exploratory process - simply about whether to 'go forward' or not. But the crucial questions in such areas are typically not just about 'yes or no?', 'how fast?' or 'who's winning?' What often matters more instead, are queries over 'which way?', 'what alternatives?', 'who says?' and 'why?' (Stirling 2011c). And the scope for uncertainties under these wider questions, compound the scope for controversy. So conflicts can become especially intensive and disabling (and potentially economically disastrous) if these broader questions are ignored.

Across all fields, the key challenge is that there exists no single definitive 'sound scientific' or 'evidence based' way to calculate the most rational balance of resources to expend on alternative innovation pathways within or across different domains (Stirling 2010b). A robust knowledge base and rigorous analysis are both necessary. But these are typically insufficient. The merit rankings constructed for different innovation choices by expert analysis invariably overlap, and may often be inverted, under contrasting equally reasonable assumptions and value judgements (Stirling 1997; Sundqvist et al. 2004; Stirling and Mayer 2001; Saltelli et al. 2004; Amendola 2001). Decisions concerning which kinds (or areas or aims) of innovation to prioritise are therefore inherently partly subjective, rather than purely technical or economic. This is why research and innovation remain intrinsically political matters, irrespective of whether or not they are acknowledged to be so.

This makes it all the more important that high quality information concerning public policy in and around innovation, is available for wider scrutiny and debate. But the recent House of Lords Select Committee on Science and Technology report on the setting of priorities for publicly funded research, identified several important areas for improvement (House of Lords 2010). The Committee confirmed that there remains important scope for enhancing the quality of official United Kingdom (UK) statistics concerning public support for contrasting innovation pathways. It made recommendations that this information be clarified in several particular ways. Yet these recommendations remain to be implemented. Consequently, further deliberate efforts are required in order to enable more transparent and accountable democratic politics concerning the directions and rationales underlying UK innovation policy. 


\section{Steering Innovation Pathways}

One reason why it is important to address the politics of choice in innovation, is that chosen pathways can quickly become effectively irreversible. A diversity of well understood social, political and economic processes exert various kinds of positive feedback as innovation pathways unfold. These can act to reinforce the trajectories favoured by the most powerful interests, and exclude others that may be more widely beneficial.

Typically, it takes a lot of effort for people, organisations and markets to learn about any new way of doing things, to capitalise on the opportunities and to adapt to the changed requirements. As these efforts become 'sunk investments' in a particular innovation, they can help reinforce commitments to the associated pathway. This can occur, even if the innovation in question is widely seen to be unsatisfactory (Antonelli et al. 2006). Although complicated (Liebowitz and Margolis 1990), a classic example of this remains the QWERTY keyboard (David 1985; David 1997). This was originally designed for nineteenth century mechanical typewriters, specifically to adjust typing in order to reduce jamming of the type bars for letters frequently used together. But this very property of modulating typing speed, helps aggravate office injuries (Amell and Kumar 1999). There exist better keyboard configurations (Noyes 1983). Yet the deeply socially embedded familiarity of QWERTY makes it difficult for alternatives to become established. So, the problem persists through successive innovations in electronic typewriters, computers and touchscreen tablets, continuing several technological generations after the initial rationale lapsed. Even where the incumbent innovation is essentially a product of historical chance, then - with no powerful backing - it can prove very difficult to reverse the associated path dependency.

This dynamic of path dependency makes it especially important to do whatever is achievable at the earliest stages of innovation, to give confidence that unfolding directions are as appropriate as possible (Wilsdon and Willis 2004). The dilemma is, of course, that this is precisely the time when the positive and negative implications are most uncertain (Collingridge 1982; Collingridge 1980). So there can be enormous pressures on all sides, to exaggerate the confidence with which evidence can be interpreted and to understate the scope for competing interpretations (Shaxson et al. 2009). One reasonable response to this, is to be much more open and questioning about uncertainties (Stirling $2010 \mathrm{~b})$. Another rational measure, is to extend scrutiny beyond anticipated consequences and also look at the driving purposes of innovation (Wynne 2006). Whilst the variously claimed positive, negative and indirect effects may remain uncertain, the motivating values, interests and incentives that lie behind particular innovation pathways are typically much clearer (Wynne 2002). In this way, critical appraisal of the driving forces behind alternative innovation pathways (not just the claimed aims) can be undertaken with confidence at an early stage, despite the uncertainties (Wilsdon et al. 2005).

This kind of careful broad-based societal consideration is, however, rarely evident in mainstream innovation. More often, it is a narrower range of expectations about the future that most strongly drive directions for change. The values upheld by particular communities of researchers themselves may be influential, as well the interests of leading firms, powerful financiers or particular users (Pollock and Williams 2010). If a specific pathway is strongly held to be more likely than others by these kinds of influential actors, then this can become self-fulfilling (van Lente 2012). Examples include competing media formats or software operating systems, where early market penetration can be driven more strongly by expectations about future adoption, than by assessments of performance (Arthur 2009). Some degree of performance shortfall is often the price for collective compatibility (David and Rothwell 1996). Consequently, expectations can add to path dependencies 
mentioned above, compounding the 'locking in' of a particular innovation, and the 'crowding out' of alternatives (Chesbrough et al. 2006). This is an issue that arises, for instance, from the conditions described in Box Y in the case of nanotechnology (Nuffield Council 2012).

Processes of learning, volume production and economies of scale can add to these positive feedbacks. For instance, 'lock in' can be significantly further reinforced by measures to standardise infrastructures (Blind 2013), establish organisational momentum (Hughes 1983), appropriate intellectual property (Chou and Shy 2013; Hilgartner 2009), build monopolies (La Porte 1991), realise rent on value chains (Kaplinsky 2000), condition user preferences through marketing (Winner 1977), 'capture' regulators (Sabatier 1975) and 'entrap' competing political interests (Walker 2000). The overall result of such so-called 'network externalities', are a range of powerful 'increasing returns' that can entrench a particular favoured trajectory and exclude other paths (Arthur 1989). Despite being ignored in the apparently simple policy language of 'going forward', these more complex dynamics in science and innovation do not go unnoticed by interests wishing variously to reinforce (or disrupt) particular pathways (Goldacre 2009; Rowell 1996). So, if innovation policy is to be fair and effective, it is therefore important that it attends to these processes in explicit, direct and accountable ways.

These challenges are formidable enough. But, as indicated above, problems of 'lock in' are intensified where important roles are also played by the deliberate exercise of powerful interests at the earliest stages of an innovation process, in order intentionally to promote particular favoured pathways or disadvantage others (Laufer 2003; Krimsky 2003). For instance, automobile manufacturers and allied industries sought historically to promote the car by suppressing competing urban public transport systems (Newman and Kenworthy 1989). Likewise, lead compounds were promoted as anti-knocking agents in transport fuels at the expense of less profitable alcohol-based products, even though these were very early known to be less harmful (EEA 2013). A further example of this more deliberate type of lock-in includes the strategies of the tobacco industry over the past century to maintain high levels of consumption (Oreskes and Conway- 2010). Before it was finally abandoned in most countries, the nuclear fuel reprocessing industry also worked for many decades actively to engineer continuing government support (Walker 2000). And now, ostensibly disinterested debates over alternative radioactive waste management strategies also inherently depend on - and help condition - future prospects for new nuclear power (Scrase and MacKerron 2009; CoRWM 2006). Most recently, pharmaceutical industry strategies have been challenged for neglecting innovation of medically vital antimicrobials due to their low profitability (Davies 2011). Where innovation systems are driven by these kinds of dynamics there are especially important roles for democratically responsive government policy and collaborative international pressure.

It is crucial not to misunderstand the implications of 'lock in'. In order to be successfully achieved, even the most positive innovation pathway will require some closing down in associated standards, regulations and practices (Stirling 2008). So 'lock in' in some sense, is not in itself necessarily a bad thing. But it remains a significant policy dilemma, since it means that not all potentially good innovations that are technically practicable, economically feasible or socially viable will actually prove to be historically realisable. The most important point then, is that these issues need to be discussed and addressed openly - and democratically - rather than brushed under the carpet or drowned in simplistic and polarising 'pro' claims (or 'anti' accusations) over innovation in general. 


\section{Opening Up Innovation Portfolios}

Many of the above examples are retrospective and judged with the benefit of hindsight. Looking forward in any given area, it becomes even more difficult to conclude definitively which of a variety of innovation pathways offers the most favourable balance of pros and cons. One especially important prospective example lies in the field of innovation for more sustainable global food systems (Baulcombe et al. 2009). How will a growing world population be fed at a time when natural environments are increasingly stressed (BIS 2011b)? Here there exists a particularly rich diversity of possible innovation pathways, each with contrasting implications (IAASTD 2009). Many kinds of diversity are possible (Pretty 2002). But public debates display a shared tendency on all sides to close down discussions as if about just being 'for' or 'against' the single family of innovations around GM, favoured by the most powerful interests in this sector.

With resulting policy debates polarised by this especially deep form of power play (Wright 2013; HoC 2014), it is often portrayed as if GM were, self-evidently and in-principle, either individually indispensable or uniquely unacceptable. Whatever reasonable political perspectives are taken on the pros and cons of the many disparate innovation pathways in this field, neither of these positions is actually tenable. In fact, the much-discussed (apparently specific) innovation of 'GM plant breeding' is much more complex and ambiguous than is often suggested by either critics or advocates alike. Apparently technical variations like 'transgenics', 'cisgenics', 'apomixis', 'gene editing', 'genomic assist' and 'marker selection' (Poltronieri and Reca 2014) each offer partly overlapping and partly contrasting benefits and risks, and present important differences in their potential social, political, economic and ecological implications (Watts 2014).

For example, among the more striking recent claims made for UK Government supported research towards enhanced Sustainability in global staple crops, are the remarkable flood tolerance qualities reported for 'scuba rice' (POST 2012). But these have been achieved through 'marker assisted backcrossing', rather than any form of transgenics (IRRI 2009). So, the most important factor typically differentiating GM technologies is not that they offer a unique means to secure crop improvement. The crucial distinction lies more often in the potential for innovating firms to recoup investments by obtaining rents on intellectual property or global supply and value chains (Jansen and Vellema 2004). For instance, transgenic crops are often deliberately engineered for tolerance to particular proprietary broad spectrum herbicides, thus expanding their sales (Benbrook 2012). Or the inclusion of particular transgenes can make the resulting organisms patentable, and thus more reliable sources of royalties (Palombi 2009). It is the resulting forces and counterforces that help make the ensuing discussions so regrettably polarised.

This point becomes even more important as attention extends beyond science-intensive innovations. Outside the techniques of molecular genetics, there are many other promising innovations for improving global food sustainability (IAASTD 2009). These include participatory breeding (FAO 2011), agricultural extension services (Leeuwisen 2004) and open source seed sharing methods (Lockie and Carpenter 2009), which harness the innovative capacities of farmers themselves and help tailor crop development to important local conditions (Altieri and Nicholls 2005). Likewise, there exist many innovations in wider agricultural practices that also offer significant benefits to the productivity of small farmers (Uphoff 2002), including intercropping (Lichtfouse 2009), integrated pest management (Radcliffe et al. 2009) and other methods of ecological farming (Sauerborn 2013) and Sustainable agriculture (Pretty 2005). 
Likewise organisational innovations in the food chain also offer potentially major benefits, including reforms to distribution systems, storage provision and better food waste management (Gustavsson et al. 2011). Arguably the greatest implications for equitable global food availability, however, are presented by innovations that are still wider in scope (Lang and Heasman 2004), including reforms to land tenure and agricultural property rights (FAO 2011), income support for marginal famers (Guyomard et al. 2004), social equality between different rural groups (Sen 2000), or moving diets towards lower meat consumption (IAASTD 2009). These kinds of innovation may often offer significantly greater benefits to poor farmers, consumers or communities than science-intensive technological solutions. But their less attractive commercial benefits mean they remain, like Cinderella, too often uninvited to the innovation party.

What is shown by this food sector example, is that - even in a specific area - innovation is not about simply 'forging ahead', 'lagging behind' or 'catching up' (Stirling 2010a). It is not a single-track race driven by a particular privileged field of science. Instead, it is about diversity, exploration and choice. This is why it is misleading to uphold particular pathways as offering exclusively 'sound scientific', definitively 'evidence based' or uniquely 'pro innovation' options (...or for all contingently-emerging innovation to be asserted necessarily to be 'great'). And this is why exaggerated 'no alternatives' language (on any side) can polarise controversy and so also impede effective innovation policy. By seeking to invoke the general authority of science and technology in partisan ways, this kind of language does not only threaten effective innovation, it also risks compromising science and undermining democracy itself (Crouch 2004). More mature and rational debate recognises that choosing between the pros and cons of alternative innovation pathways, like those exemplified here, are less technical than they are political.

A more reasonable and productive way to handle these crucial issues in innovation policy is to be more transparent, deliberate and accountable about when it is right to 'open up' and when to 'close down' in any particular field (Stirling 1998). This means that no particular innovation should be unduly favoured by policy making simply because of its appeal to particular powerful vested interests within a given innovation system. Nor should it be treated on these grounds as self-evidently existentially unacceptable. Either position requires context and perspective-specific argument. In other words, what is needed is mature political debate as much as ostensibly definitive analysis (Stilgoe 2009). What can be recognised as well, though, are the benefits of some requisite degree of diversity (Stirling 2011d). And (as we shall see) this is a general quality that can be achieved in many different ways - also potentially excluding any particular innovation.

This can be illustrated by the further example of the challenge of mitigating climate change by building zero carbon energy infrastructures. Here decades of intensive research by government and industry bodies has shown that there exist (despite the formidable constraints) a range of alternative innovation pathways that are viable under contrasting equally-informed understandings (IPCC 2012). For some, the solutions centre around nuclear power (Nuttall 2005). Others highlight large scale use of carbon capture and storage (Meadowcroft and Langhelle 2009). In the wings, momentum is growing behind expedient and idealised aspirations somehow deliberately to control the global climate through 'geoengineering' (Shepherd 2009; Fleming 2010; Ridgwell et al. 2012; Ruddiman 2005; IPCC WG1 2013) - a technology threatening particularly acute and irreversible forms of 'lock in' (Cairns and Stirling 2014; Cairns 2014). Yet all the time (albeit not backed by such powerful interests), a rich array of renewable energy technologies is available for addressing climate change in a diversity of radically different distributed or centralised ways (EREC 2010; ECF 2010a; PWC 2010; WWF 2011).

The crucial point is, that there is no definitive technical or economic reason why any of the above energy strategies cannot (for better or worse) provide a basis for a variety of zero carbon UK or global energy futures. Crucially, this includes the clear feasibility (equally for the UK and Europe 
(Anon 2002; Pugwash 2013; ECF 2010b; WWF 2011; WBGU 2004; GEA 2012) and the world as a whole (IPCC 2012; Jacobson and Delucchi 2009)) of energy strategies built entirely around efficiency and renewables. Yet one of the main obstacles to this, lies in high profile self-fulfilling assertions to the contrary, including by authoritative policy figures (King 2006; MacKay 2009). In energy as in the food sector discussed above, then, the obstacles to less favoured strategies are typically more commercial, institutional and cultural than they are technical. Amongst the most potent of these political obstructions are claims from partisan interests - like incumbent nuclear or fossil fuel industries - that there exists 'no alternative' to their favoured innovations and policies (King 2006). Even given the formidable constraints bearing on sustainable energy and agriculture then (Rockström et al. 2009) there remains much hidden scope for radical choice. This is a matter for critical democratic deliberation as much as technical analysis (Stirling 2014a).

There are many ways to resist such unhelpful syndromes and to develop more reasonable debates about innovation. These will be returned to below. Some are about the style of discourse developing a greater tolerance on all sides, for embracing adverse public reactions to particular innovations. When they transcend privileged 'not in my backyard' parochialisms, general public preferences offer an important guide to the general orienting of innovation (Devine-Wright 2011). Just as scepticism is one of the crucial constituting qualities in science itself (Lakatos and Musgrave 1970; Popper 1962), so space for healthy critical debate and public dissent can help improve the quality of innovation more generally (Stirling 2011b; Rip 1987). With mainstream institutions often especially strongly disciplined by incumbent powerful interests, the role of delivering on this important quality of scepticism often falls disproportionately to civil society (Leach et al. 2005).

And this crucial role of social movements and wider civil society extends beyond debate and controversy. It is remarkable how many current major global industries are building around oncemarginal technologies like wind turbines, ecological farming, super energy-efficient buildings, or green chemistry (Smith et al. 2013). All of these owe key elements in their pioneering origins to early development by grassroots social movements (Garud and Karnøe 2003). For instance, without the small country of Denmark remaining partly 'below the radar' of international nuclear interests, able to nurture alternative energy strategies in the 1970s driven strongly by anti-nuclear social movements, it is arguable that the present multinational wind industry might never have become competitive (Karnoe and Jorgensen 1991). This is just one of the examples of innovations that were systematically marginalised - sometimes actively suppressed - by incumbent interests in science, government and industry (Fressoli et al. 2014).

It is of course important not to become too romantic about the dynamics of social movements and their favoured innovations (Leach et al. 2005). These too warrant exactly the same kinds of healthy scepticism appropriate to other actors in innovation debates. But history does make clear where it is that many of the ostensibly driving environmental and social justice concerns that currently play such prominent roles in the justification of innovation policy come from. Without decades of struggle by social movements dedicated to humanitarianism, environmentalism and social justice, it is doubtful that high level global agenda-setting developments like the Stockholm Environment Conference or the Brundtland Commission or the Millennium Development Goals would ever have become as formative as they are now in shaping the general climate of global governance - or innovation debates, in particular (Dryzek et al. 2003; Redclift 1987; Ekins 1992; Hess 2007; Voss et al. 2006; Leach et al. 2003; Adger and Jordan 2009). Here, the same basic pattern is arguably reproduced, as in the crucial roles played by social movements in other emancipatory transformations around colonialism, slavery, women's and gay rights (Fanon 1964; Davis 2014; Sudbury 1998; Paletschek and Pietrow-Ennker 2004). 
Just as the famous astronomical missing mass stabilises the visible structures of galaxies, so these apparently intangible distributed social forces help condition the gradients that ultimately help forge and steer new directions for innovation (Stirling 2014a). The greater the critical interest in the most progressive orientations for innovation - rather than those that preserve the status quo - the more this is generally true. 


\section{Risk, Uncertainty, Ambiguity and Ignorance}

As has been mentioned, these policy making challenges are compounded, because the pros and cons of different innovation pathways are - under all views - subject to seriously incomplete knowledge. The normal way to address these dilemmas, is by means of regulatory risk assessment (PCCRARM 1997; IRGC 2005; HMT 2005). Although often not implemented in full, this prevailing approach invokes the apparent authority of probabilistic analysis (Porter 1995; GOS 2012; Hacking 2006) to assert a notionally single 'sound scientific' or 'evidence-based' picture (Wolpert 1992; Taverne 2005; Byrd and Cothern 2000; WHO 1999). This task can be approached in many variously complex ways (Suter 2006; Burgman 2005; Hester and Harrison 1998). But at root, it involves alternative possible positive and negative outcomes being weighted by their respective perceived likelihoods to derive a single overall 'expected value' for the balance of future benefits and harms (Lofstedt 2011; GOS 2012).

In conventional innovation policy and regulation then, it is simply assumed that whatever products or technologies are most energetically advanced for assessment of risk are in some way self-evidently beneficial (Freemantle 1999; Jasanoff 2004). Questions then typically focus on whether any associated risks will be 'tolerable' (HSE 2001; Bouder et al. 2007; ONR 2006). It is rare for the claimed benefits themselves to be rigorously scrutinised (Bentkover et al. 1986), let alone compared in a balanced way with other potential benefits of alternative innovation pathways (O'Brien 2000; Harremoës et al. 2000). So existing forms of risk regulation do little to address the wider issues in innovation politics discussed above.

Further challenges arise in the reliance of risk-based regulation on the methods provided by probability theory (Hacking 2001; Keynes and Lewis 1922). Probabilistic tools can be useful in tackling familiar, high-frequency, relatively unchanging challenges, as found (for instance) in risk regulation of many urban transport or public health systems (Adams 1995; WHO 2013). Where empirical evidence arising from past experience is held to be a reliable guide to the future, these tools can be very powerful - as in established responses to familiar safety risks (Renn and Dreyer 2009). But where an innovation pathway (or its context) is novel, complex or rapidly changing, uncertainties cannot confidently be reduced to single definite probabilities (Aven and Renn 2010). Such inabilities to justify a single picture of probabilities can arise, for instance, in the regulation of nanotechnologies (IRGC 2007), endocrine disrupting chemicals (Royal Society 2000), or novel living organisms (Millstone et al. 1999). Under these conditions, it can be irrational to assert a single definitive 'evidence based' picture (Stirling and Scoones 2009). In these fields (as more widely), policy making must often contend with contrasting, but equally reasonable, interpretations of uncertainty (Shaxson et al. 2009; Stirling 2010b). These cannot reliably or rationally be reduced to simple single numbers for probabilities.

These are not the only limits to risk assessment. Beyond uncertainty in the above sense (Lewis and Keynes 1922; Knight 1921; Rowe 1994), there exists a further array of challenges (Wynne 1992; Funtowicz and Ravetz 1989). These involve not the relative likelihoods of different outcomes, but the meanings of the possibilities themselves. For instance, divergent views may exist over how to categorise or partition different kinds of benefit or harm. Or there may be major questions over how to frame the various dimensions under which these are defined (Goffman 1976). What are the appropriate imaginations, understandings, values, or interests according to which they should be interpreted or prioritised (Jasanoff and Kim 2009)? There may also be differences over which innovation pathways to include or exclude from scrutiny, or how to allocate attention (Collingridge 1982). 
These are challenges of ambiguity, rather than strict uncertainty (Stirling 1999). Here, the problem is not so much about uncertainty, as contradictory certainties (Thompson and Warburton 1985). And risk assessment is no more able fully to resolve these disagreements over meanings as over likelihoods (Shrader-Frechette 1991). Indeed, Nobel Prizes have been awarded in rational choice theory, for axiomatic proofs demonstrating there can be no definitive way to guarantee the calculation of a particular optimum balance between contending ways to interpret, measure or prioritise possible outcomes (Kelly 1978; Arrow 1963; MacKay 1980). Yet such challenges remain not only the norm in many innovation debates, but they constitute the key issues in contention in controversies like those over alternative agricultural, energy or health strategies (Sarewitz 2004). Under ambiguity, claims to single definitive 'sound scientific' or 'evidence-based' prescriptions are not only seriously misleading, they are oxymorons (Stirling 2006b).

The above difficulties may seem tricky enough. But even more intractable than uncertainty and ambiguity, is the further challenge of ignorance (Loasby 1976; Collingridge 1980; Wynne 1992; Stirling 2003). Here possibilities are not just disagreed about but, at least some, are entirely unexpected (Funtowicz and Ravetz 1989; Faber and Proops 1998). This was the case, for instance, in the early regulatory history of bovine spongiform encephalopathy (BSE) (Zwanenberg and Millstone 2000), endocrine disrupting chemicals (Thornton 2000) and damage by chlorofluorocarbons (CFCS) to stratospheric ozone (Hoffmann 2005). Like many other cases (Harremoës et al. 2000; EEA 2013), these involved mechanisms that were not just thought unlikely at the inception of the issue, but were at the time 'unknown unknowns' (Randall 2011). Where we don't know what we don't know (Wynne 2002) the prospect is raised of possible 'black swans' (Taleb 2007). These challenges are not about calculable risk, but inherently unquantifiable surprises (Brooks and Cantley 1986; Rosenberg 1996). Here again, to seek to assign single definite values for 'risk' is not just irrational but dangerous (Stirling et al. 2001).

Of course, surprise is not necessarily always a bad thing. It is intrinsic to the rationale for 'blue skies' science - as well as research and innovation more generally - that positive benefits can also be entirely unexpected (Brooks and Cantley] 1986). An example might be the laser - a novel laboratory phenomenon that was for a long time a tool without a use (Bertolotti 1999). Likewise (albeit involving many variously questionable applications), the internet has also undoubtedly given rise to a host of positive benefits that were initially entirely unexpected (Szoka and Marcus 2010). But it is also clear, for instance in areas like nanotechnology (Swierstra and Rip 2007), that there is no guarantee that further research will necessarily reduce uncertainty, ambiguity or ignorance (Stirling 2009). As Einstein famously observed, it is often the case that the more we learn, the more we find we don't know (ESRC 2007). And, of course, this is not necessarily bad. Indeed, it is a key motivation in science (Ravetz 1987). It is political pressures that resist the humility of acknowledging ignorance (Jasanoff 2003).

Either way, it is clear that some of the greatest dilemmas in innovation governance extend well beyond risk: they are about surprises. With conventional regulatory risk assessment entirely unable to deal with this deepest form of incertitude, the importance of robust critical deliberation and wider political argument about innovation, is seriously reinforced. 


\section{Precaution and Diversity}

One widely established and intensely debated response to these challenges in innovation policy, is the precautionary principle (O'Riordan et al. 2001; Boehmer-Christiansen 1994; Harding and Fisher 1999) . Although it comes in many forms (Fisher 2002), a classic general expression of precaution is that scientific uncertainty is not a reason for inaction in preventing serious damage to human health or the environment (UNEP 1992). By explicitly hinging on uncertainty rather than risk, precaution helps promote recognition that social choices in innovation are not reducible to ostensibly precise, value-free, technical risk assessments (Raffensperger and Tickner 1999). These dilemmas are instead explicitly recognised to involve wider issues and alternatives requiring overtly value-based - and so 'political' in this sense - deliberations over policy.

This message is inconvenient to many partisan perspectives wishing to dragoon the authority of science as a whole in favour of specific interests (Marchant and Mossman 2004). Often driven by such motives, opposition to precaution rests largely on assertions (or assumptions) that established 'science based' regulatory risk assessment offers a sufficient general response to the challenges of social choices across alternative innovation pathways, and a particular way to justify favoured technologies (Morris 2000; Goklany 2001). So precaution remains a subject of much misunderstanding and mischief (Sunstein 2005; Graham 2004; Holm and Harris 1999; Martuzzi and Tickner 2004). This often involves ironically emotive rhetoric in supposed defence of reason (Taverne 2005). It is on these grounds, for instance, that arguments are sometimes made that it is somehow irrational not to always use probabilities to qualify potential hazards (Beddington 2013). In this way, many critics of precaution mistakenly ignore uncertainty, ambiguity and ignorance, insisting instead that these be treated as if they were risk (Lofstedt 2011). The precautionary principle has played a crucial role in fostering more rational reflection about these highly political pressures on the use and abuse of science in technology regulation.

Treating general dilemmas of uncertainty, ambiguity and ignorance as a simple state of risk, perpetrates the misunderstandings discussed above, that probabilistic analysis is universally applicable and that innovation is a single-track race. When these misapprehensions are corrected, precaution can be recognised simply as a guide to the more reasonable and realistic steering of social choice among possible innovation pathways (Stirling 2007b). So precaution is not (as often alleged) about being somehow generally 'anti-innovation' or 'anti-science' (Dekkers et al. 2013; Tait 2009; Taverne 2005). Instead, it simply urges greater rational consideration of different aspects of incertitude than can reasonably be reduced merely to risk (Stirling 2001b; Randall 2011; Luj and Todt 2014; Harremoës et al. 2000; Felt et al. 2008).

Consequently, precaution does not automatically mean abandoning any particular innovation, still less innovation in general (Hopkins and Nightingale 2006). Contrary to many claims (Marchant and Mossman 2004), there is nothing inherent in the precautionary principle that automatically requires bans (CEC 2000), or makes it partisan in its applicability to innovations of contrasting provenance (Stirling 2001a; Levidow and Marris 2001). Precautionary action inhibiting any one innovation pathway inevitably favours another (Luj and Todt 2014). And precaution does not even mean abandoning risk assessment (Dreyer et al. 2007; Renn and Dreyer 2009). It simply reminds that riskbased approaches do not offer a complete response to deeper challenges of choice.

Precaution is also a guard against the error of treating absence of evidence of harm as evidence of absence of harm (Ravetz 2004). This is often a particular danger for innovations whose novelty means there has been little time for evidence to accumulate, or where incumbent interests 
discourage research or assessment of the requisite kinds (Stirling and Gee 2002). Before invoking a lack of evidence of harm, it is necessary to think about how visible this evidence might actually be expected to be if it existed, or how vigorously it is sought (McGlade et al. 2013). Identifying false negatives is often more important than avoiding false positives (EEA 2013). In this respect, precaution is a guard against wilful and misleading blinkers favouring incumbent interests and the inertia of the status quo (Stirling 2011a).

In essence, precaution simply highlights that innovation policy and associated politics should pay more careful attention to the intrinsically problematic nature of knowledge, and its vulnerability to economic and political pressures. But it does not just highlight problems. The precautionary principle also opens the door to solutions, pointing to a range of rigorous and practical strategies and practices for dealing with the realities of uncertainty, ambiguity and ignorance in innovation (Harremoës et al. 2000; Stirling et al. 2001; Raffensperger and Tickner 1999; Stirling 2007; Saltelli et al. 2008; Ferson et al. 2003; Warren-Hicks and Hart 2010; Swart et al. 2008; Van Asselt and Rotmans 2002). These 'Cinderella methods' can be neglected, where there persist preoccupations solely with deterministic notions of 'risk', 'exposure' and 'vulnerability' (rather than 'uncertainty', 'ambiguity' and 'ignorance'), and a consequent sense that risk assessment alone is sufficient (Stirling 2001a). Practical examples include a range of different tools for 'opening up' regulatory appraisal (Petersen et al. 2011), research strategies (Ely et al. 2013) and innovation policy (Stirling 2012), as well as more general prioritising of qualities like reversibility (Dovers 1995), resilience (Dovers and Handmer 2013) and flexibility (Tickner and Wright 2003).

Rather than resting hubristically on an ostensibly definitive picture in the balancing of benefits and harms, these precautionary strategies acknowledge stronger grounds for greater humility (Jasanoff 2003). Instead of wishful thinking about the quality of risk information, they prioritise more humble measures to consider alternatives, explore uncertainties, maximise learning (Wynne 1992) and promote adaptability (Fisher et al. 2002) in careful, reversible, step-by-step implementation (Lujan and Todt 2007). Where there is uncertainty over probabilities, potential hazards do remain relevant in their own right, with particular care necessary where they might be irreversible (CEC 2000). And the dilemmas are accentuated where associated infrastructures might also prove to be especially inflexible (Stirling 2001a). All else being equal, where a range of innovation pathways look as if they present similar balances of pros and cons, precaution simply highlights that it is reasonable to prioritise that which is more reversible over the less flexible alternatives (Rip 1999).

At root, a key value of precaution lies in helping to free policy debates from the Panglossian fallacy that the most powerfully favoured innovation pathways are somehow necessarily the best or only option (Lane et al. 2009). It reminds us that particular values (other than profit), also need to be prioritised, especially around human health and environmental integrity (de Sadeleer 2007). This enables societies to discuss rationally and directly when it is right for governance deliberately to discourage or discontinue a particular entrenched trajectory (Stegmaier et al. 2012). The crucial point is, that precaution makes this possible without incurring existential anxieties over innovation in general. As a general principle, it offers a practical and flexible means to avoid simply relying on optimistic hopes that powerful vested interests will automatically be spontaneously relinquished or themselves become entirely benign.

And in this, precaution points to a further quality in research and innovation systems, namely diversity. Even though it is not a panacea, nor a 'free lunch' (Weitzman 1992), nor self-evident in its composition, diversity is a vital consideration in research and innovation policy (Stirling 2007a). Like other strategies, it brings its own challenges and remains intrinsically a matter for political judgement. But in any given area, recognition of the importance of diversity encourages caution about concentrating resources in support of the particular innovations that happen to be favoured by 
the most powerful interests (Stirling 1994). Diversity urges instead greater attention to alternatives, leading to more deliberately and systematically-constituted portfolios comprised of some balanced variety of disparate innovation pathways (Stirling 2007a).

In these terms, diversity offers a remarkably practical way to help address several otherwise intractable innovation problems. It offers a 'resource pool' (Breznitz 1986), helps to nurture creativity (Page 2007), mitigates lock-in (Arthur 1989), hedges against surprise (Norgaard 1994), accommodates ambiguity (Grabher and Stark 1997), resolves irreconcilable interests (James 1990), promotes learning (Wynne 1992) and cultivates resilience (Folke et al. 2002). And, by fostering more intensive encounters between varying kinds of knowledge and practice, deliberate diversification can also help enhance innovation processes themselves (Rosenberg 1982) and make them more effective and socially robust (Nowotny 2003). It is remarkable to find so many otherwise intractable challenges addressed (albeit always provisionally and incompletely) by a single operational strategy. And there exist plenty of useful tools to help focus more concretely at the level of diverse innovation portfolios, rather than individual programmes (Yoshizawa et al. 2011; Grubb et al. 2006; Skea 2010).

Consequently, deliberate diversification is one key pragmatic way to enable greater precaution, while also helping to diffuse unhelpful polarisation in debates over innovation (Stirling 2005). This is aided by more explicit and measured pursuit of repertoires of innovations in particular areas, rather than single privileged supposedly 'sound scientific', 'evidence based', 'solutions'. Moreover, a focus on diversity may also help develop greater political tolerance, for the otherwise difficult, but inevitable, kinds of failure that are so essential to effective learning (Geels and Smit 2000). If commitments lie at the level of diverse portfolios rather than single supposedly 'no alternative' solutions, then it becomes easier to accept and justify the kinds of failures that contribute so much to learning.

To help realise these concrete benefits, however, diversity must move away from being a fig leaf or argument-of-last-resort for some otherwise ill-favoured but powerfully-backed choice (Stirling 2014b). It is all too easy to support otherwise indefensible proposals, simply on the grounds that 'we must do everything' (Stirling 2010c). This invites powerful interests to insist on adoption of their own preferred policy, simply on grounds that every option must be pursued (Lawson 1992). There are typically many kinds of diversity, each exclusive in some ways and inclusive in others (Stirling 1994) (Andy Stirling 2010c). So, as with individual innovation pathways, the detailed constituting of diversity also involves inherently political judgements. By urging this greater attention to diversity (as in other ways), precaution can be as much a spur to innovation in general, as a brake on any specific kind. 


\section{Three Key Conclusions}

Formulating a adequate response to the challenges discussed in this paper requires being clear about the resulting practical implications for policy. Here, there have been many recent interventions developing concrete recommendations for research and innovation practices and the wider policy procedures and political debates in which these are set. The European Science Foundation reviewed key background in research and innovation systems across Europe (Felt et al. 2013). The Expert Group on Science and Governance put this in the context of the European 'Knowledge Society' (Felt et al. 2008). The Nuffield Council on Bioethics recommended new institutional ways more effectively to govern emerging technologies (Nuffield Council 2012). The Engineering and Physical Sciences Research Council (EPSRC) identified a number of responsibilities to be encouraged across all actors in innovation systems (Brooks 2014). An Economic and Social Research Council (ESRC)-funded 'new manifesto' explores some of the global implications (STEPS 2010). And many other international initiatives contribute much further detail (BEPA 2010; Stirling et al. 2006; Sclove 2010). But the general practical upshot is quite readily summarised in terms of three overarching principles: participation, responsibility and precaution (Stirling 2011a).

First, there is public participation in innovation. Here, innovation strategies should more explicitly and transparently acknowledge the inherently partly political (rather than restrictively technical) nature of the interests and motivations driving contending pathways. This requires many forms of sincere, well-resourced, participatory deliberation, especially including the most marginalised interests (Leach et al. 2010). This is not about fostering credibility, trust or acceptance, but about informing policy and helping substantively to determine the priority directions for research and innovation themselves (Fiorino 1990). Nor is participation about 'political correctness' or relativism about science (implying a position that 'anything goes' (Feyerabend 1975)). Indeed, it offers the most effective way to draw on wider knowledges in order to illuminate how dominant narrow understandings are often untenable. In essence, public participation in innovation is simply about more rigorous exploration of specific ways in which legitimate judgements about 'benefits', 'excellence', 'relevance', 'risk', 'evidence' and 'impact' all depend in part (but irreducibly), on contexts, values and assumptions.

In other words, public participation addresses the fact that what counts as a positive direction for research and innovation in any given area is inherently 'plural and conditional' (Stirling 2008). Plural because a number of contrasting pathways are typically equally valid (Bussu et al. 2014). Conditional because this validity depends partly on perspectives and circumstances. A rich variety of carefullydeveloped inclusive, participatory and deliberative practices are available to address this challenge, with varying kinds of value in different circumstances (Kass 2001; Mohr et al. 2014; Smith 1966; Fischer 2009; OECD 2001; Grove-White et al. 1997; Blamey et al. 2000; Stirling et al. 2007). And crucially, participation does not just mean talking about innovation, but also inclusion in the means for supporting the actual doing of innovation itself (Smith et al. 2013; Porter and Linde 1995; Fressoli et al. 2014; BEPA 2010; Fonseca and Pereira 2013; Tornatzky et al. 1980). Here, there are key roles for the creative arts, humanities and local communities as well as workers and civil society more generally. Some approaches are more formally structured than others, involving uninvited as well as invited participation (Wynne 2007). Together, these help open up deeper and wider explorations of practical alternatives (Stirling 2012). In this way, diverse styles of public participation supplement, enrich and inform (rather than substitute), the conventional procedures of representative democracy (Stirling 2006a). Freed from pressures to pretend at (potentially enormously expensive and 
protracted) ostensibly singular definitive evidence based status, unfolding processes of innovation can become not only more democratically accountable and legitimate, but also more efficient and timely.

Alongside (and mutually reinforcing) greater participation, there is a second major policy imperative. This is for all actors involved in research and innovation processes - especially the most powerful to assume more direct and explicit responsibility for the consequences and uncertainties of their activities. This in turn requires serious efforts on the part of innovators to be reflective in anticipating, analysing and addressing the impacts that might arise, as well as their attendant ambiguities and unknowns. It helps avoid the 'organised irresponsibility of otherwise 'passing the buck' to insurers, regulators, victims, the state, or 'society' at large to deal with inevitable unintended and indirect outcomes (Beck 1992). And (assisted by participation) responsibility involves being more openly accountable for motivating aims and interests. So responsibility is not about aspiring, let alone claiming, to predict or control consequences (Stilgoe et al. 2013). Nor is it abut simple exhortations to trust (Pellizzoni 2005). Instead, responsibility is about trustworthiness (Krefting 1991). It means going beyond conventional narrow institutional and economic interests, to care (and be accountable) for wider social and environmental concerns and implications.

A crucial aim of responsibility is that scientists, engineers, businesses, regulators - and government itself - move away from fixations merely with risk around whatever are the particular privileged pathways for innovation in given fields. Instead, responsibility on the part of these influential actors, helps inform and open the necessary space for participation by others by illuminating contending motives and a range of alternative directions for progress. Nor is there anything about this that necessarily impedes decision making on innovation, or makes it more protracted or burdensome. Indeed, by helping to avert ill-advised trajectories at an early stage, participation and responsibility can assist innovation to become more effective in addressing diverse social values of a kind that might otherwise invite a costly backlash (Owen et al. 2013). But there do arise here, particular responsibilities for the media. The discussion in this paper has shown that it is quite simply irresponsible to pretend (as is too often the case (Observer 2014)) that science and technology are free of interests, values or alternatives (Rowell 2004; Miller and Dinan 2008). What is required instead, is less simplistic and romantic portrayals of technical expertise (Moore and Stilgoe 2009). The media hold especially important responsibilities for enabling more realistic, mature and open debates about the inherently contestable and power-laden nature of both scientific knowledge and technological innovation (Allan et al. 1999).

This leads to the third and final general policy implication. This is, that greater and more deliberate efforts are needed to moderate the powerful forces of closure and lock-in in science and technology. It is here that this paper has shown the particular value of precaution in regulation. Rather than treating existing patterns of research and innovation as value-free, the precautionary principle strikes an explicitly stronger balance in favour of human health, environmental integrity and social wellbeing in the steering of priority directions. Thus guided (but not determined) by precaution, participation and responsibility can explore and elucidate more clearly what might be meant by these values in any given context. So together, these complementary principles and practices help provide a selection and balancing process, to harness incumbent and energetic private interests. In particular, precaution directly addresses the tendencies for uncertainties, ambiguities and ignorance to be closed down in the most convenient directions, as if they were just 'risk'.

When innovation is recognised as a branching rather than a single-track process, it becomes clear also that precaution is not about impeding innovation, but about steering it in ways that better favour human health and the environment. Acknowledging the scope for systematic deliberation over values, priorities and alternatives under uncertainty, precaution broadens out risk regulation to 
allow greater space for responsibility and participation, and greater consideration for a wider plurality of issues, options, perspectives and scenarios. This can help enable entrepreneurs, small business, new entrants, civil society groups and marginalised communities (as well as government) to better challenge established trajectories. As we have seen, precaution also implies a greater focus on qualities of diversity, flexibility and responsiveness in technology strategies. A final key lesson of precaution is that regulation and innovation policy should seek to respect and embrace (rather than manage or curtail) public mobilisation and critical dissent. In essence, precaution expresses the fundamental principle that, in innovation just as in science itself, reasoned scepticism fosters greater quality.

In concluding this paper, then, we can return to a point made at the beginning. In any given area, innovation is not so much about a race to optimise a single pathway, as it is a collaborative process for exploring diverse alternatives. Current noisy anxieties over falling behind in single-track zero sum competitive innovation races are misleading and counterproductive. They can conceal underlying motives, interests and alternatives, as well as and supressing the associated politics. Instead, interrelated practices of responsibility among researchers and innovators, precaution in regulatory processes and participation in policy making and innovation itself, can help innovation escape from these restrictive fear-driven technical imperatives. They illuminate instead how innovation is fundamentally about the politics of contending hopes (Stirling 2014a). Most importantly of all, it is in these ways that narrow technocratic ideas of a knowledge economy (Felt et al. 2008), can give way to the nurturing of a more inclusive, rational and vibrant innovation democracy. 


\section{Bibliography}

Abraham, J. and Sheppard, J. (1997) 'Democracy, Technocracy, and the Secret State of Medicines Control: Expert and Nonexpert Perspectives', Science, Technology \& Human Values 22.2: 139-167, http://sth.sagepub.com/cgi/doi/10.1177/016224399702200201 (30 July 2013)

Adams, J. (1995) Risk, London: Routledge

Adger, W. N. and Jordan, A. (eds) (2009) Governing sustainability, Cambridge: Cambridge University Press

Alic, J. (2009) Energy Innovation Systems from the Bottom Up, Washington DC: CSPO/CATF

Alic, J. A. (2007) Trillions for Military Technology: how the Pentagon innovates and why it costs so much, New York: Palgrave MacMillan

Allan, S., Adam, B. and Carter, C. (1999) Environmental risks and the media, S. Allan, B. Adam, and C. Carter (eds), London: Routledge

Altieri, M .A. and Nicholls, C. I. (2005) Agroecology and the Search for a Truly Sustainable Agriculture, Colonia Lomas de Virreyes: UNEP

Amell, T. K. and Kumar, S. (1999) 'Cumulative trauma disorders and keyboarding work', International Journal of Industrial Ergonomics 25.1: 69-78

Amendola, A. (2001) 'Recent paradigms for risk informed decision making', Safety Science 40.1-4: $17-30$

Anon (2011) Neuroscience, society and policy, London: The Royal Society

- (2010) Who Owns Science? The Manchester Manifesto, Manchester: University of Manchester

- (2002) The Energy Review, London: The Cabinet Office

Antonelli, C., Foray, D., Hall, B. H. and Steinmuller, W. E. (eds) (2006) New Frontiers in the Economics of Innovation and New Technology: essays in honour of Paul A. David, Cheltenham: Edward Elgar

Arrow, K.J. (1963) Social Choice and Individual Values, New Haven CT: Yale University Press

Arthur, W.B. (1989) 'Competing Technologies, Increasing Returns, and Lock-in by Historical Events', The Economic Journal 99.394: 116-131

Arthur, W. B. (2009) The Nature of Technology: What It Is and How It Evolves, London: Penguin

Aven, T. and Renn, O. (2010) Risk Management and Governance: concepts, guidelines, applications, Heidelberg: Springer

Beck, U. (1992) Risk Society: Towards a New Modernity, London: SAGE 
Beddington, J. (2013) 'Addressing the challenges of the 21st century', Foundation for Science and Technology Journal, 21.1: 4-7

Benbrook, C. M. (2012) 'Impacts of genetically engineered crops on pesticide use in the US - the first sixteen years', Environmental Sciences Europe 24: 1-13

Bentkover, J. D., Covello, V. T. and Mumpower, J. (eds) (1986) Benefits Assessment: the state of the art, Dordrecht: Reidel

BEPA (2010) Empowering people, driving change: social innovation in the European Union, Brussels: Bureau of European Policy Advisors, European Commission

Berkhout, F., Leach, M. and Scoones, I. (eds) (2003) Negotiating Environmental Change: new perspectives from social science, Cheltenham: Edward Elgar

Bertolotti, M. (1999) The History of the Laser, London: Institute of Physics

BIS (2011a) Innovation and Research: Strategy for Growth, BIS Economics Paper 15, London: Department for Business, Innovation and Skills

- (2011b) The Future of Food and Farming: challenges and choices for global sustainability, London: Department for Business, Innovation and Skills

- (no date) 'Innovation is Great... Britain', poster, London: Deparment for Business, Innovation and skills, http://i.telegraph.co.uk/multimedia/archive/02004/great-innovation 2004849i.jpg

Blamey, R .K., James, R. F., Smith, R. and Niemeyer, S. (2000) Citizens' juries and environmental value assessment, Canberra: Australian National University

Blind, K. (2013) The Impact of Standardization and Standards on Innovatio, Nesta Working Paper 13/15, London: NESTA

Boehmer-Christiansen, S. (1994) 'The Precautionary Principle in Gemany - enabling Government', Chapter 2 in O'Riordan, T. and J. Cameron (eds), Interpreting the Precautionary Principle, London: Earthscan

Bohmann, J. (1996) Public Deliberation: pluralism, complexity and democracy, Cambridge MA: MIT Press

Borgmann, A. (1988) 'Technology and Democracy' in M. E. Kraft and N. J. Vig (eds) Technology and Politics, Durham and London: Duke University Press

Bouder, F., Slavin, D. and Lofstedt, R. E. (2007) The Tolerability of Risk, London: Earthscan

Bound, K. and Thornton, I. (2012) Our Frugal Future: lessons from India's Innovation System, London NESTA

Breznitz, S. (1986) 'Educating for coping with change', pp 32-41 in D. Hamburg and M. Frankenheuser (eds) Ancient humans in tomorrows electronic world, Washington DC: Aspen Institute

Broers, A. (2005) The Triumph of Technology, Cambridge: Cambridge University Press 
Brooks, E. C. (2014) Framework for responsible innovation, Engineering and Physical Sciences Research Council, http://www.epsrc.ac.uk/research/framework/ (29 June 2014)

Brooks, H. and Cantley, M. (1986) 'The Typology of Surprises in Technology, Institutions and Development' in W. C. Clark and R. E. Munn (eds) Sustainable Development of the Biosphere, Cambridge: Cambridge University Press

Burgman, M. (2005) Risks and Decisions for Conservation and Environmental Management, Cambridge: Cambridge University Press

Bussu, S., Davis, H. and Pollard, A. (eds.) (2014) The best of Sciencewise reflections on public dialogue, London: Sciencewise

Byrd, D. M. and Cothern, C. R. (2000) Introduction to Risk Analysis: a systematic approach to science based decision making, Oxford: Government Institutes Press

Cable, V. (2011) 'Oral statement to Parliament: Innovate 2011', London

Cairns, R. C. (2014) 'Climate geoengineering: issues of path-dependence and socio-technical lock-in', WIREs C limate Change 5.5: 649-661, DOI: 10.1002/wcc.296

Cairns, R. and Stirling, A. (2014) 'Maintaining Planetary Systems' or 'Concentrating Global Power?' High Stakes in Contending Framings of Climate Geoengineering', Global Environmental Change, 28: 25-38

CEC (2012) Reaping the benefits of globalization: European Competitiveness Report 2012, Brussels: Commission of the European Communities

- (2009) Gearing European Research towards Sustainability: RD4SD Exercise, Brussels: Commission of the European Communities

- (2006) Working Document on the contributions of the future regional policy to the innovative capacity of the European Union Committee on Regional Development, Brussels: Commission of the European Communities

- (2000) Communication from the Commission on the Precautionary Principle, Brussels: Commission of the European Communities

Chesbrough, H., Vanhaverbeke, W. and West, J. (eds) (2006) Open Innovation: Researching a New Paradigm, Oxford: Oxford University Press

Chou, C. and Shy, O. (2013) 'The crowding-out effects of long duration of patents', The RAND Journal of Economics 24.2: 304-312

Cimbala, S. J. (2005) Nuclear Weapons and Strategy: US nuclear policy for the twenty-first century, London: Routledge

Cirincione, J. (2007) Bomb scare: the history and future of nuclear weapons, New York: Columbia University Press

Collingridge, D. (1982) Critical Decision Making: a new theory of social choice, London: Frances Pinter 
Collingridge, D. (1980) The Social Control of Technology, Milton Keynes: Open University Press

CoRWM (2006) Managing our radioactive wastes safely: CoRWM's recommendations to Government, London: Committee on Radioactive Waste Management, http://www.corwm.org.uk

Crouch, C. (2004) Post Democracy, London: Wiley

David, P. A. (1985) 'Clio and the Economics of QWERTY', Economic History, 75.2: 332-337

David, P. A. (1997) Path Dependency and the Quest for Historical Economics: one more chorus of the ballad of QWERTY, University of Oxford Discussion Papers 20, Oxford: University of Oxford

David, P. A. and Rothwell, G. S. (1996) 'Standardisation, Diversity and Learning: strategies for the coevolution of technology and industrial capacity', International Journal of Industrial Organization 14.2: 181-201

Davies, B., Baulcombe, D., Crute, I., Dunwell, J., Gale, M., Jones, J., Pretty, J., Sutherland, W. and Toulmin, C. (2009) Reaping the benefits: science and the sustainable intensification of global agriculture, London: Royal Society

Davies, S. A. (2011) Infections and the rise of antimicrobial resistance: Annual Report of the Chief Medical Officer, Volume II, London: Department of Health

Davis, D. B. (2014) The Problem of Slavery in the Age of Emancipation, New York: Knopf

De Sadeleer, N. (ed.) (2007) Implementing the Precautionary Principle: approaches from the Nordic countries, the EU and the USA, London: Earthscan

Dekkers, M., Bock, K., Rubsamen, H., Liveris, A., Hansen, R., Galindez, A., Rorsted, K., van Dorenmalen, H., Jiminez, J., van Houten, F., Clamadieu, J-P. and Mack, M. (2013) The Innovation Principle: stimulating economic recovery, an open letter to Mr José Manuel Barroso, Brussels

Delucchi, M. A. and Jacobson, M. Z. (2011) 'Providing all global energy with wind, water, and solar power, Part II: Reliability, system and transmission costs, and policies', Energy Policy 39.3: 1170-1190

Devine-Wright, P. (ed.) (2011) Renewable Energy and the Public: from NIMBY to participation, London: Earthscan

Dosi, G. (2000) Innovation, Organization and Economic Dynamics - Selected Essays, Cheltenham: Edward Elgar

Dovers, S. and Handmer, J. W. (2013) 'Ignorance, the Precautionary Principle, and Sustainability', Ambio 24.2: 92-97

Dovers, S. R. (1995) 'A framework for scaling and framing policy problems in sustainability', Ecological Economics 12: 93-106

Dreyer, M., Renn, O., Ely, A., Stirling, A., Vos, E. and Wendler, F. (2007) A General Framework for the Precautionary and Inclusive Governance of Food Safety, Brussels: European Community

Dryzek, J. S. (2003) Green States and Social Movements: environmentalism in the United States, United Kingdom, Germany and Norway, Oxford: Oxford University Press 
ECF (2010a) Roadmap 2050: a practical guide to a prosperous, low carbon Europe, Brussels: European Climate Foundation

-(2010b) Roadmap 2050: policy recommendations, Policy Report Volume 2, Brussels: European Climate Foundation

EEA (2013) Late lessons from early warnings: science, precaution, innovation, Copenhagen: European Environment Agency

Ekins, P. (1992) A New World Order: Grassroots Movements for Global Change, London: Routledge

Ely, A., Van Zwanenberg, P. and Stirling, A. (2013) 'Broadening out and opening up technology assessment: Approaches to enhance international development, co-ordination and democratisation', Research Policy, 43.3: 505-518, doi:10.1016/i.respol.2013.09.004

ERAB (2012) The new Renaissance: will it happen? Innovating Europe out of the crisis - Third and final report of the European Research Area Board 2012, Brussels: European Research Area Board

EREC (2010) Rethinking 2050: a 100\% renewable energy vision for the EU, Brussels: European Renewable Energy Council

ESRC (2007) Science, technology and globalisation, Swindon: Economic and Social Research Council, Science in Society Programme

Eurobarometer (2005) Population Innovation Readiness, Brussels: European Commission

European Commission (2009) Reinvent Europe Through Innovation: from a knowledge society to an innovation society, Brussels: European Commission

Faber, M. and Proops, J. L. R. (1998) Evolution, Time, Production and the Environment, Berlin, Heidleberg, New York: Springer

Fanon, F. (1964) Toward the African Revolution, New York: Grove Press

FAO (2011) Save and Grow: a policymaker's guide to the sustainable intensification of smallholder crop production, Rome: United Nations Food and Agriculture Organization

Felt, U., Barben, D., Irwin, A., Joly, P-B., Rip, A., Stirling, A. and Stöckelová, T. (2013) Science in Society: caring for our futures in turbulent times, Strasbourg: European Science Foundation

Felt, U. and Wynne, B. (eds) (2008) 'Taking European knowledge society seriously: report of the Expert Group on Science and Governance to the Science, Economy and Society Directorate, Directorate-General for Research, European Commission', Brussels: European Commission

Ferson, S. (2003) Constructing Probability Boxes and Dempster-Shafer Structures, Albuquerque and Livermore: Sandia National Laboratories

Feyerabend, P. (1975) Against Method, London: Verso

Fiorino, D. J. (1990) 'Citizen Participation and Environmental Risk: a survey of institutional mechanisms', Science, Technology and Human Values 15.2: 226-243 
Fischer, F. (2009) Democracy and Expertise: reorienting policy inquiry, Oxford: Oxford University Press

Fisher, E. (2002) 'Precaution, Precaution Everywhere: Developing a "Common Understanding" of the Precautionary Principle in the European Community', Maastricht Journal of International and Comparative Law 9: 7-28

Fisher, E., Jones, J. and von Schomberg, R. (eds) (2002) Implementing the precautionary principle: perspectives and prospects, Cheltenham: Edward Elgar Publishing

Fleming, J. R. (2010) Fixing the Sky: the checkered history of weather and climate control, New York: Columbia University Press

Folke, C., Carpenter, S., Elmqvist, T., Gunderson, L., Holling, C. S. and Walker, B. (2002) 'Resilience and Sustainable Building Adaptive Capacity in a World of Transformations', AMBIO: a Journal of the Human Environment 31.5: 437-440

Fonseca, P. F. C. and Pereira, T. S. (2013) 'The governance of nanotechnology in the Brazilian context: Entangling approaches', Technology in Society, 37: 1-12, http://linkinghub.elsevier.com/retrieve/pii/S0160791X13000626 (28 January 2014)

Foresight Horizon Scanning Centre (2012) Technology and Innovation Futures: UK Growth Opportunities for the 2020s, London: Foresight Horizon Scanning Centre

Freemantle, N. (1999) 'Does the UK National Health Service need a fourth hurdle for pharmaceutical reimbursement to encourage the more efficient prescribing of pharmaceuticals?', Health Policy 46: $255-265$

Frenken, K. (2004) 'The early development of the steam engine: an evolutionary interpretation using complexity theory', Industrial and Corporate Change 13.2: 419-450, http://icc.oupjournals.org/cgi/doi/10.1093/icc/dth017 (15 January 2014)

Frenken, K., Saviotti, P. P. and Trommetter, M. (1999) 'Variety and niche creation in aircraft, helicopters, motorcycles and microcomputers', Research Policy 28.5: 469-488

Fressoli, M., Around, E., Abroi, D., Smith, A., Ely, A. and Dias, R. (2014) 'When grassroots innovation movements encounter mainstream institutions: implications for models of inclusive innovation', Innovation and Development 4.2: 277-292

Funtowicz, S. O. and Ravetz, J. R. (1989) 'Scientific Uncertainty and Quality Evaluation in Technology Scenarios and R\&D Programmes' in Energy Technologies for Reducing Greenhouse Emissions, Paris: OECD

Garud, R. and Karnøe, P. (2003) 'Bricolage versus breakthrough: distributed and embedded agency in technology entrepreneurship', Research Policy 32.2: 277-300

GEA (2012) Global Energy Assessment Toward a Sustainable Future, G. Davis and J. Goldemberg (eds), Cambridge: Cambridge University Press

Geels, F. W. and Smit, W. A. (2000) 'Lessons from Failed Technology Futures: Potholes in the Road to the Future', pp. 129-156 in N. Brown, B. Rappert, and A. Webster (eds) Contested Futures. A Sociology of Prospective Techno-science, London: Ashgate 
Goffman, E. (1976) Frame Analysis: An Essay on the Organization of Experience, Cambridge MA: Harvard University Press

Goklany, I. M. (2001) The Precautionary Principle: a critical appraisal of environmental risk assessment, Washington DC: Cato Institute

Goldacre, B. (2009) Bad Science, London: Harper

GOS (2012) Review of high impact low probability risks: Blackett Review, London: Government Office for Science

Grabher, G. and Stark, D. (1997) 'Organizing Diversity: Evolutionary Theory, Network Analysis and postsocialism', Regional Studies 31.5: 533-544

Graham, J. D. (2004) 'The Perils of the Precautionary Principle: Lessons from the American and European Experience', Heritage Lecture 818, Washington DC: The Heritage Foundation

Grove-White, R., Macnaghten, P., Mayer, S. and Wynne, B. (1997) Uncertain World: genetically modified organisms, food and public attitudes in Britain, Lancaster: CSEC, Lancaster University, (http://www.lancs.ac.uk/users/csec/)

Grubb, M., Butler, L. and Twomey, P. (2006) 'Diversity and security in UK electricity generation: The influence of low-carbon objectives', Energy Policy 34.18: 4050-4062, http://linkinghub.elsevier.com/retrieve/pii/S0301421505002442 (3 November 2012)

Gustavsson, J., Cederberg, C., Sonesson, U., van Otterdijk, R. and Meybeck, A. (2011) Global food losses and food waste: extent, causes and prevention, Rome: FAO

Guyomard, H., le Moue, C. and Gohin, A. (2004) 'Impacts of alternative agricultural income support schemes on multiple policy goals', European Review of Agricultural Economics 31.2: 125-148

Hacking, I. (2001) An Introduction to Probability and Inductive Logic, Cambridge: Cambridge University Press

Hacking, I. (2006) The Emergence of Probability: a philosophical study of early ideas about probability, induction and statistical inference (2nd ed.), Cambridge: Cambridge University Press

Hall, B. and Rosenberg, N. (eds) (2010) Handbook of the Economics of Innovation - Volume 1, Amsterdam: Elsevier

Harding, R. and Fisher, E. (1999) Perspectives on the precautionary principle, Annandale NSW: Federation Press

Harremoës, P., Gee, D., MacGarvin, M., Stirling, A., Keys, J., Wynne, B. and Guedes Vaz, S. (2000) Late lessons from early warnings: the precautionary principle 1896-2000, Copenhagen: European Environment Agency

Harris, M. and Albury, D. (2009) The Innovation Imperative: why radical innovation is needed to reinvent public services for the recession and beyond, NESTA: London

Hess, D. J. (2007) Alternative Pathways in Science and Industry: activism, innovation and the environment in an era of globalisation, Cambridge MA: MIT Press 
Hester, R. E. and Harrison, R. (eds) (1998) Risk Assessment and Risk Management, London: Royal Society of Chemistry

Hilgartner, S. (2009) 'Intellectual Property and the Politics of Emerging Technology: inventors, citizens, and powers to shape the future', Chicago-Kent Law Review 81.1: 197-224

HMT (2005) Managing Risks to the Public: Appraisal Guidance, London: The Treasury

HOC (2014) GM Foods and Application of the Precautionary Principle in Europe, London: House of Commons

Hoffmann, M. J. (2005) Ozone Depletion and Climate Change: Constructing a Global Response, Albany: State University of New York Press

Holm, S. and Harris, J. (1999) 'Precautionary principle stifles discovery', Nature 400.6743: 398, http://www.ncbi.nlm.nih.gov/pubmed/10440359

Hopkins, M. M. and Nightingale, P. (2006) 'Strategic risk management using complementary assets: Organizational capabilities and the commercialization of human genetic testing in the UK', Research Policy 35.3: 355-374

House of Lords (2010) Setting priorities for publicly funded reseach - Volume I: Third Report of Session 2009-2010, London: House of Lords, Science and Technology Committee

HSE (2001) Reducing risks, protecting people: HSE's decision making process, London: Health and Safety Executive

Hughes, T. (1983) Networks of Power: electrification in western society 1880-1930, Baltimore: Johns Hopkins University Press

IAASTD (2009) Agriculture at a Crossroads: international assessment of agricultural knowledge science and technology for development (IAASTD), Washington: Island Press

IPCC (2012) Renewable energy sources and climate change mitigation: special report of the Intergovernmental Panel on Climate Change, Cambridge: Cambridge University Press, http://www.cro3.org/cgi/doi/10.5860/CHOICE.49-6309

IPCC WG1 (2013) Fifth Assessment Report: Summary for Policymakers, Geneva: Intergovernmental Panel on Climate Change

IRGC (2007) Nanotechnology Risk Governance Recommendations for a global coordinated approach to the governance of potential risks, Geneva: International Risk Governance Council

-(2006) Risk governance: towards an integrative approach, Geneva: International Risk Governance Council

-(2005) An introduction to the IRGC Risk Governance Framework, Geneva: International Risk Governance Council

IRRI (2009) Scuba rice: breeding flood-tolerance into Asia's local mega rice varieties, Manila: International Rice Research Institute 
Jackson, T. (2009) Prosperity without growth? The transition to a sustainable economy, London: Earthscan

Jacobson, M. Z. and Delucchi, M. (2011) 'Providing all global energy with wind, water, and solar power, Part I: Technologies, energy resources, quantities and areas of infrastructure, and materials', Energy Policy 39.3: 1154-1169, http://linkinghub.elsevier.com/retrieve/pii/S0301421510008694 (28 February 2013)

Jacobson, M.Z. and Delucchi, M. A. (2009) 'A Plan to Power 100 Percent of the Planet with Renewables', Scientific American, November: 1-5

James, P. (1990) 'Energy, Environment and Rationality', Energy and Environment, 1990: 114-123

Jansen, K. and Vellema, S. (eds) (2004) Agribusiness and Society: corporate responses to environmentalism, market opportunities and public recognition, London: Zed Books

Jasanoff, S. (ed) (2004) States of Knowledge: the co-production of science and social order, London: Routledge

Jasanoff, S. (2003) 'Technologies of Humility: citizen participation in governing science', Minerva 41: 223-244

Jasanoff, S. (1996) 'The Dilemma of Environmental Democracy', Issues in Science and Technology 13.1: $63-70$

Jasanoff, S. and Kim, S-H. (2009) 'Containing the Atom: Sociotechnical Imaginaries and Nuclear Power in the United States and South Korea', Minerva 47.2: 119-146, http://www.springerlink.com/index/10.1007/s11024-009-9124-4 (1 November 2012)

Kaldor, M. (2007) Human Security: Reflections on Globalization and Intervention, Cambridge: Polity Press

Kaplinsky, R. (2000) 'Globalisation and Unequalisation: What Can Be Learned from Value Chain Analysis?', Journal of Development Studies 37.2: 117-146, http://www.tandfonline.com/doi/abs/10.1080/713600071

Karnoe, P. and Jorgensen, U. (1991) 'The Danish Wind Turbine Story - Technical Solutions to Political Visions?' in A. Rip, J, Mise. And J. Schot (eds), Managing Technology in Society: The Approach of Constructive Technology Assessment, London/New York: Pinter

Kass, G. (2001) Open Channels: public dialogue in science and technology, Post Report 153, London: Parliamentary Office of Science and Development

Kearnes, M. and Rip, A. (2009) 'The Emerging Governance Landscape of Nanotechnology', pp.1-35 In S. Gammel, A. Lösch, and A. Nordmann (eds) Jenseits von Regulierung: Zum politischenUmgang mit Nanotechnolog, Berlin: Akademische Verlagsgesellschaft

Kelly, J. S. (1978) Arrow Impossibility Theorems, New York: Academic Press

Keynes, J. M. and Lewis, C. I. (1922) 'A Treatise on Probability', The Philosophical Review 31.2: 180, http://www.jstor.org/stable/2178916?origin=crossref 
King, D. (2006) 'David King: Why we have no alternative to nuclear power: if there were other sources of low carbon energy I would be in favour, but there aren't', 2 February 2006, The Independent: 1-4

Knight, F. H. (1921) Risk, Uncertainty and Profit, Boston: Houghton Mifflin

Krefting, L. (1991) 'Rigor in Qualitative Research: the assessment of trustworthiness', American Journal of Occupational Therapy 45.3: 214-222

Krimsky, S. (2003) Science in the Private Interest: has the lure of profits corrupted biomedical research, Oxford: Rowman and Littlefield

Lakatos, I. and Musgrave, A. (eds) (1970) Criticism and the Growth of Knowledge: Proceedings of the International Colloquium in the Philosophy of Science, Aberdeen: Aberdeen University Press

Lane, D., Maxfield, R., Reed, D. and van der Leeuw, S. (eds) (2009) Complexity Perspectives in Innovation and Social Change, Berlin: Springer

Lang, T. and Heasman, M. (2004) Food Wars: the global battle for mouths, minds and markets, London: Earthscan

Laufer, W. S. (2003) 'Social Accountability and Corporate Greenwashing', Journal of Business Ethics 43: $253-261$

Lawson, N. (1992) The View from Number 11: memoires of a Tory radical, London: Bantam Press

Leach, M., Scoones, I. and Stirling, A. (2010) Dynamic Sustainabilities: technology, environment, social justice, London: Routledge

Leach, M., Scoones, I. and Wynne, B. (2005) Science and Citizens: globalization and the challenge of engagement, London: Zed Books

Leeuwisen, C. (2004) Communication for Rural Innovation Rethinking Agricultural Extension, Oxford: Blackwell

Van Lente, H. (2012) 'Navigating foresight in a sea of expectations: lessons from the sociology of expectations', Technology Analysis \& Strategic Management 24.8: 769-782, http://www.tandfonline.com/doi/abs/10.1080/09537325.2012.715478 (31 July 2013)

Levidow, L. and Marris, C. (2001.) 'Science and governance in Europe: lessons from the case of agricultural biotechnolog', Science and Public Policy 28.5: 345-360

Lewis, C. I. and Keynes, J. M. (1922) 'A Treatise on Probability', The Philosophical Review 31.2: 180, http://www.jstor.org/stable/2178916?origin=crossref

Lichtfouse, E. (2009) Climate Change, Intercropping, Pest Control and Beneficial Microorganisms, Berlin: Springer

Liebowitz, S. J. and Margolis, S. E. (1990) The Fable of the Keys. Journal of Law and Economics, 30.1: $1-26$ 
Lightman, A., Sarewitz, D. and Desser, C. (eds) (2003) Living with the Genie: essays on technology and the quest for human mastery, Washington DC: Island Press

Lilley, S. (2013) Transhumanism and Society: the social debate over human enhancement, Dordrecht: Springer Netherlands

Loasby, B.J. (1976) Choice, Complexity and Ignorance: am inquiry into economic theory and the practice of decision making, Cambridge: Cambridge University Press

Lockie, S. and Carpenter, D. (eds) (2009) Agriculture, Biodiversity and Markets: livelihoods and agroecology in comparative perspective, London: Earthscan

Lofstedt, R. (2011) Reclaiming health and safety for all: An independent review of health and safety legislation, London: Department of Work and Pensions

Luj, L. and Todt, O. (2014) 'Analyzing Precautionary Regulation: Do Precaution, Science, and Innovation Go Together?', Risk Analysis 34.12: 2163-73

Lujan, J. L. and Todt, O. (2007) 'Precaution in public: the social perception of the role of science and values in policy making', Public Understanding of Science 16.1: 97-109, http://pus.sagepub.com/cgi/doi/10.1177/0963662506062467 (5 June 2013)

Mackay, A. F. (1980) Arrow's Theorem: the paradox of social choice - a case study in the philosophy of economics, New Haven NT: Yale University Press

MacKay, D. J. C. (2009) Sustainable Energy - without the hot air, Cambridge: UIT

Malerba, F. and Brusoni, S. (eds) (2007) Perspectives on Innovation, Cambridge: Cambridge University Press

Malhotra, A., Schulte, J., Patel, P. and Petesch, P. (2009) Innovation: for Women's Empowerment and Gender Equality, Washington DC: International Center for Research on Women

Marchant, G. and Mossman, K.L. (eds) (2004) Arbitrary and Capricious: the precautionary principle in the European Union courts, Washington DC: American Enterprise Institute

Martuzzi, M. and Tickner, J. A. (eds) (2004) The precautionary principle: protecting public health, the environment and the future of our children, Copenhagen: World Health Organization

Mazzucato, M. (2013) The Entrepreneurial State: debunking public vs private sector myths, London: Anthem Press

McGlade, J., Quist, D. and Gee, D. (2013) 'Social Responsibility for New Technologies', Nature 497.7449: 317, http://www.ncbi.nlm.nih.gov/pubmed/23676744

McLeish, C. and Nightingale, P. (2007) 'Biosecurity, bioterrorism and the governance of science: The increasing convergence of science and security policy', Research Policy 36.10: 1635-1654, http://linkinghub.elsevier.com/retrieve/pii/S00487333307002089 (22 October 2013)

Meadowcroft, J. and Langhelle, O. (eds) (2009) Caching the Carbon: the politics and policy of carbon capture and storage, Cheltenham: Edward Elgar 
Miller, D. and Dinan, W. (2008) A Century of Spin: How Public Relations Became the Cutting Edge of Corporate Power, London: Pluto Press

Miller, P. and Wilsdon, J. (eds) (2006) Better Humans: the politics of human enhancement and life extension, London: Demos

Millstone, E., Brunner, E. and Mayer, S. (1999) 'Beyond " substantial equivalence"', Nature, 401.6753: 525-6, http://www.ncbi.nlm.nih.gov/pubmed/10524614

Mohr, A., Raman, S. and Gibbs, B. (2014) Which publics? When? Exploring the policy potential of involving different publics in dialogue around scienc and technology, Didcot: Sciencewise-ERC

Moore, A. and Stilgoe, J. (2009) 'Experts and Anecdotes: The Role of Anecdotal Evidence in Public Scientific Controversies', Science, Technology \& Human Values 34.5: 654-677, http://sth.sagepub.com/cgi/doi/10.1177/0162243908329382 (3 December 2013)

Morris, J. (ed.) (2000) Rethinking Risk and the Precautionary Principle, London: Butterworth Heinemann

Murray, R., Caulier-Grice, J. and Mulgan, G. (2009) Social Venturing, London: The Young Foundation/NESTA

Nelson, R. and Winter, S. (1982) An Evolutionary Theory of Economics Change, Cambridge MA: Harvard University Press

Nath, C. and Wentworth, J. (2012) GM in Agricultural Development, POSTnote Report 412, London: Parliamentary Office of Science and Development

NESTA (2011) Compendium of Evidence on Innovation Policy, Manchester: NESTA, http://www.innovation-policy.net/compendium/

- (2006) The Innovation Gap: Why policy needs to reflect the reality of innovation in the UK, Policy Briefing, London: NESTA

Newman, P. and Kenworthy, J. (eds) (1989) Cities and Automobile Dependence, an International Sourcebook, Aldershot: Gower

Norgaard, R. B. (1994) Development Betrayed: the end of progress and a coevolutionary revisioning of the future, London: Routledge

Kaldor, M., Albrecht, U., Chinkin, C., Dervis, K., Dwan, R., Giddens, A., Gnesotto, N., Licht, S., Pronk, J., Reinhardt, K., Schmeder, G., Seifter, P. and Serra, N. (2004) A Human Security Doctrine for Europe, the Barcelona report of the Study Group on Europe's Security Capabilities Presented to EU High Representative for Common Foreign and Security Policy Javier Solana, London: London School of Economics

La Porte, T. R. (ed.) (1991) Social Responses to Large Technical Systems: Control or Anticipation, Dordrecht: Springer

Nowotny, H. (2003) 'Democratising expertise and socially robust knowledge', Science and Public Policy, 30.3: 151-156 
Noyes, J. A. N. (1983) 'The QWERTY keyboard: a review', International Journal of Man-Machine Studies 18: 265-281

Nuffield Council (2012) Emerging biotechnologies: technology, choice and the public good, London: Nuffield Council of Bioethics

Nuttall, W. J. (2005) Nuclear Renaisance: Technologies and Policies for the Future of Nuclear Power, Bristol: Institute of Physics Publishing

O'Brien, M. (2000) Making Better Environmental Decisions: an Alternative to Risk Assessment, Cambridge MA: MIT Press

O'Neill, J. (1993) 'Pluralism, Incommensurability, Judgement', Chapter 7 in J. O'Neill, Ecology, Policy and Politics: Human Well-Being and the Natural World, London: Routledge

O'Riordan, T., Cameron, J. and Jordan, A. (2001) Reinterpreting the precautionary principle, London: Cameron May, http://www.loc.gov/catdir/toc/fy034/2001430010.html

Observer (2014) 'There's no choice: we must grow GM crops now, The Observer, 16 March 2014: 1-5

OECD (2013) Main Science and Technology Indicators: Volume 2013/1, Paris: OECD

- 2010) The OECD Innovation Strategy: getting a head start on tomorrow, Paris: OECD

- 2005) Governance of Innovation Systems - Volume 1: Synthesis Report, Paris: OECD

-(2002) Dynamising National Innovation Systems, Paris: OECD, http://www.oecdilibrary.org/industry-and-services/dynamising-national-innovation-systems 9789264194465-en

-(2001) Citizens as Partners: information, consultation and public participation in policy making, Paris: OECD

ONR (2006) Safety Assessment Principles for Nuclear Facilities, London: Office for Nuclear Regulation

Oreskes, N. and Conway, E. M. (2010) Merchants of doubt: how a handful of scientists obscured the truth on issues from tobacco smoke to global warming, London: Bloomsbury

Owen, R., Bessant, J. and Heintz, M. (eds) (2013) Responsible Innovation: managing the responsible emergence of science and innovation in society, Chichester: Wiley

Page, S. E. (2007) The Difference: how the power of diversity creates better groups, firms, schools and societies, Princeton NJ: Princeton University Press

Paletschek, S. and Pietrow-Ennker, B. (eds) (2004) Women's Emancipation Movements in the Nineteenth Century: a European Perspective, Redwood City CA: Stanford University Press

Palombi, L. (2009) Gene Cartels: biotech patents in the age of free trade, Cheltenham: Edward Elgar, http://www.elgaronline.com/view/9781847208361.xml

Parkinson, S., Pace, B. and Webber, P. (2013) Offensive Insecurity: The role of science and technology in UK security strategies, London: Scientists for Global Responsibility 
PCCRARM (1997) Risk Assessment and Risk Management In Regulatory Decision-Making, Report of the Presidential/Congressional Commission on Risk Assessment and Risk Management Washington DC: US Government Printing Office

Pellizzoni, L. (2005) 'Trust, Responsibility and Environmental Policy', European Societies 7.4: 567-594, http://www.tandfonline.com/doi/abs/10.1080/14616690500194118 (28 September 2013)

Peoples, C. (2009) Justifying Ballistic Missile Defence: technology, security and culture, Cambridge: Cambridge University Press

Petersen, A. C., Cath, A., Hage, M., Kunsler, E. and van der Sluis, J. P. (2011) 'Post-Normal Science in Practice at the Netherlands Environmental Assessment Agency', Science, technology \& human values 36.3: 362-388,

http://www.pubmedcentral.nih.gov/articlerender.fcgi?artid=3682633\&tool=pmcentrez\&rendertype =abstract (22 November 2013)

Piketty, T. (2014) Capital in the Twenty First Century, Cambridge MA: Belknap Press

Pollock, N. and Williams, R. (2010) 'The business of expectations: How promissory organizations shape technology and innovation', Social Studies of Science 40.4: 525-548, http://sss.sagepub.com/cgi/doi/10.1177/0306312710362275 (30 July 2013)

Poltronieri, P. and Reca, I. B. (2014) 'Transgenic, Cisgenic and Novel Plant Products, Regulation and Safety Assessment' in P. Poltronieri and Y. Hong (eds) Applied Plant Genomics and Biotechnology, Cambridge: Elsevier Woodhead

Popp, D. and Newell, R. G. (2009) Where Does Energy R\&D Come From? Examining Crowding Out from Environmental friendly R\&D, NBER Working Paper 15423, Cambridge MA: National Bureau of Economic Research

Popper, K. (1962) Conjectures and Refutations, New York: Basic Books

Porter, M. E. and van der Linde, C. (1995) 'Green and Competitive: Ending the Stalemate', Harvard Business Review 73.5 (September-October)

Porter, T. M. (1995) Trust in Numbers: the pursuit of objectivity in science and public life, Princeton NJ: Princeton University Press

Pretty, J. (2002) Agri-Culture: reconnecting people, land and nature, London: Earthscan

Pretty, J. (ed.) (2005) The Earthscan Reader in Sustainable Agriculture, London: Earthscan

Pugwash (2013) Pathways to 2050 : Three possible UK energy strategies, London: British Pugwash Group

PwC (2010) 100\% renewable electricity: A roadmap to 2050 for Europe and North Africa, PwC Report, London: PricewaterhouseCoopers

Radcliffe, E. B., Hutchinson, W. D. and Cancelado, R. E. (eds) (2009. Integrated pest management: concepts, tactics, strategies and case studies, Cambridge: Cambridge University Press 
Raffensperger, C. and Tickner, J. A. (eds.) (1999) Protecting public health \& the environment: implementing the precautionary principle, Washington DC: Island Press

Randall, A. (2011) Risk and Precaution, Cambridge: Cambridge University Press

Ravetz, J. (2004) 'The post-normal science of precaution', Futures 36.3: 347-357, http://linkinghub.elsevier.com/retrieve/pii/S0016328703001605 (20 August 2013)

Ravetz, J. R. (1987 'Usable Knowledge, Usable Ignorance: Incomplete Science with Policy Implications', Science Communication 9.1: 87-116, http://scx.sagepub.com/cgi/doi/10.1177/107554708700900104 (11 November 2012)

Redclift, M.(1987) Sustainable Development: exploring the contradictions, London: Routledge

Rejali, D. (2007) Torture and Democracy, Princeton: Princeton University Press

Renn, O. (2008) Risk Governance: coping with uncertainty in a complex world, London: Earthscan

Renn, O. and Dreyer, M. (eds) (2009) Food safety governance: integrating science, precaution and public involvement, Berlin: Springer, http://dx.doi.org/10.1007/978-3-540-69309-3

Rescher, N. (1993) Pluralism: against the demand for consensus, Oxford: Clarendon Press

Ridgwell, A., Freeman, C. and Lampitt, R. (2012) 'Geoengineering: taking control of our planet's climate', in Science Sees Further, (an article series): London: The Royal Society

Rip, A. (1999) 'Constructive Technology Assessment', in A. Stirling (ed.) On Science and Precaution in the Management of Technological Risk - Volume II: CaseStudies, Sevilla: Institute for Prospective Technological Studies

-(1987) 'Controversies as Informal Technology Assessment', Knowledge: Creation, Diffusion, Utilization, 8.2, 349-371

Rockström, J., Steffen, W., Noone, K., Persson, A., Stuart Chapin III, F., Lambin, E. F., Lenton, T. M., Scheffer, M., Folke, C., Schellnhuber, H. J., Nykvist, B., de Wit, C. A., Hughes, T., van der Leeuw, S., Rodhe, H., Sörlin, S., Snyder, P. K., Costanza, R., Svedin, U., Falkenmark, M., Karlbert, L., Corell, R. W., Fabry, V. J., Hansen, J., Walker, B., Liverman, D., Richardson, K., Crutzen, P. and Foley, J. A. (2009) 'A safe operating space for humanity', Nature 461: 472-475

Rogers, P. (2001) Losing Control: global security in the 21st century, London: Pluto Press

Rosenberg, N. (1982) Inside the Black Box: technology and economics, Cambridge: Cambridge University Press

Rosenberg, N. (1996) 'Uncertainty and Technological Change' in R. Landau, T. Taylor and G. Wright (eds) The Mosaic of Economic Growth, Stanford: Stanford University Press

Rowe, W.D. (1994) 'Understanding Uncertainty, Risk Analysis, 14: 743-750

Rowell, A. (2004) Don't worry [it's safe to eat]: the true story of GM food, BSE and foot and mouth, London: Earthscan 
Rowell, A. (1996) Green Backlash: Global Subversion of the Environment Movement, London: Routledge

Royal Society (2004) Nanoscience and nanotechnologies: opportunities and uncertainties, London: The Royal Society

Royal Society (2000) Endocrine disrupting chemicals (EDCs), London: The Royal Society

Royal Society and Royal Academy of Engineering (2012) Shale gas extraction in the UK: a review of hydraulic fracturing, London: Royal Academy of Engineering

Ruddiman, W. F. (2005) Plows, Plagues and petroleum: how humans took control of climate, Princeton NJ: Princeton University Press

Sabatier, P. (1975) 'Social Movements and Regulatory Agencies : Toward a More Adequate and Less Pessimistic Theory of " Clientele Capture"',Policy Sciences 6:301-342

Saltelli, A., Ratto, M., Andres, T., Campolongo, F., Cariboni, J., Gatelli, D., Saisana, M. and Tarantola, S. (2008) Global Sensitivity Analysis: The Primer, Hoboken: Wiley

Saltelli, A., Chan, K. and Scott, E. M.(2004) Sensitivity Analysis in Practice: a guide to assessing scientific methods, Chichester: John Wiley and Sons

Sarewitz, D. (2004) 'How science makes environmental controversies worse', Environmental Science \& Policy 7.5: 385-403, http://linkinghub.elsevier.com/retrieve/pii/S1462901104000620 (7 November2013)

Sauerborn, K. M. J. (2013) Agroecology, Berlin: Springer

Saviotti, P. P. and Frenken, K. (2008) 'Export variety and the economic performance of countries', Journal of Evolutionary Economics 18.2: 201-218, http://www.springerlink.com/index/10.1007/s00191-007-0081-5 (3 November 2012)

Schiller, P. L., Bruun, E. C. and Kenworthy, J. R. (2010) An Introduction to Sustainable Transportation: policy, planning and implementation, London: Earthscan

Sclove, R. E. (1995) Democracy and Technology, New York: Guildford Press

-(2010) Reinventing technology Assessment: A 21st Century Model, Washington DC: Science and Technology Innovation Program, Woodrow Wilson International Center for Scholars

Scrase, I. and MacKerron, G. (eds) (2009) Energy for the Future: A New Agenda, London: Palgrave Macmillan, http://books.google.co.uk/books?id=Wm4ZOwAACAAJ

Scrase, J. I., Smith, A. and Kern, F. (2010) Dynamics and deliberations: comparing heuristics for low carbon innovation policy, Working Paper, Brighton: Science and Technology Policy Research

Scrase I., Stirling A., Geels, F. W., Smith A. and Van Zwanenberg P. (2009) Transformative Innovation: A report to the Department for Environment, Food and Rural Affairs, Brighton: SPRU

Sen, A. (2000) Development as Freedom, New York: Knopf 
Shaxson, L., Harrison, M. and Morgan, M. (2009) Developing an evidence-based approach to environmental policy making : insights from Defra's Evidence \& Innovation Strategy, Working Paper 181, Brighton: SPRU

Shepherd, J. (2009) Geoengineering the climate: science, governance and uncertainty, London: The Royal Society

Shrader-Frechette, K. (1992) 'Technology, Bayesian Policymaking, and Democratic Process', Philosophy and Technology 9: 123-137

Shrader-Frechette, K. S. (1991) Risk and Rationality: philosophical foundations for populist reforms, Berkeley CA: University of California Press

Skea, J. (2010) 'Valuing diversity in energy supply', Energy Policy 38.7: 3608-3621, http://dx.doi.org/10.1016/i.enpol.2010.02.038

Smith, A., Fressoli, M. and Thomas, H. (2013) 'Grassroots innovation movements: challenges and contributions', Journal of Cleaner Production 63: 1-11, http://linkinghub.elsevier.com/retrieve/pii/S0959652612006786 (14 November 2013)

Smith, G. (1996) Democratic Innovations: designing instituions for citizen participation, Cambridge: Cambridge University Press

Stegmaier, B. P., Visser, V. R. and Kuhlmann, S. (2012) 'Governance of the Discontinuation of SocioTechnical Systems-An Exploratory Study of the incandescent light bulb phase-out', in The Governance of Innovation and Socio-Technical Systems in Europe: New Trends, New Challenges Panel on The governance of innovation and sociotechnical systems: design and displacements, Paper, Copenhagen.: Copenhagen Business School

STEPS (2010) Innovation, sustainability, development : a new manifesto, Brighton: STEPS Centre

Steward, F. (2008) Breaking the boundaries: transformative innovation for the global good, London: NESTA

Stilgoe, J. (2009) The road ahead-Public Dialogue on Science and Technology, London: Sciencewise Expert Resource Centre

Stilgoe, J., Owen, R. and Macnaghten, P. (2013) 'Developing a framework for responsible innovation', Research Policy 42.9: 1568-1580 http://linkinghub.elsevier.com/retrieve/pii/S0048733313000930 (7 August 2013)

Stirling, A. (2014a) Emancipating Transformations: From controlling 'the transition' to culturing plural radical progress, STEPS Working Paper 64, Brighton: STEPS Centre

-(2014b) 'Energy Research \& Social Science Transforming power : Social science and the politics of energy choices', Energy Research \& Social Science 1: 83-95, http://dx.doi.org/10.1016/j.erss.2014.02.001

-(2012) Opening Up the Politics of Knowledge and Power in Bioscience. PLoS Biol, 10.1: p.e1001233, http://dx.doi.org/10.1371/journal.pbio.1001233 (5 November 2012) 
-(2011a) 'Governance of Neuroscience: challenges and responses' pp. 87-98 in Brain Waves: neuroscience, society and policy, London: Royal Society

Stirling, A. (2011b) 'Let's Hear it For Scepticism', Research Fortnight, blog, http://exquisitelife.researchresearch.com/exquisite life/2011/02/lets-hear-it-for-scepticism-its-

suppression-is-one-of-the-principal-threats-to-science.html

-(2011c) 'Pluralising progress: From integrative transitions to transformative diversity', Environmental Innovation and Societal Transitions 1.1: 82-88, http://linkinghub.elsevier.com/retrieve/pii/S2210422411000116 (5 November 2012)

-(2011d) 'Pluralising progress: From integrative transitions to transformative diversity', Environmental Innovation and Societal Transitions 1.1: 82-88, http://www.sciencedirect.com/science/article/pii/S2210422411000116

-(2010) 'From Enlightenment to Enablement: Opening up Choices for Innovation', pp. 199-210 in A. Lopez-Claros (ed.) The Innovation for Development Report, Basingstoke: Palgrave Macmillan

-(2010a) Direction, Distribution and Diversity! Pluralising Profess in Innovation, Sustainability and Development, Brighton: STEPS Centre

-(2010b) 'Keep it complex', Nature 468: 1029-1031

-(2010c) 'Multicriteria diversity analysis: A novel heuristic framework for appraising energy portfolios', Energy Policy 38.4: 1622-1634,

http://linkinghub.elsevier.com/retrieve/pii/S0301421509000901 ( 3 November 2012)

-(2009) 'Risk, uncertainty and power', Seminar Magazine 597:33-39

-(2008) '“Opening Up" and "Closing Down": Power, Participation, and Pluralism in the Social Appraisal of Technology', Science, Technology and Human Values 23.2: 262-294

-(2007) 'Risk, precaution and science: towards a more constructive policy debate-Talking point on the precautionary principle', EMBO Reports 8.4: 309-315

-(2007a) 'A general framework for analysing diversity in science, technology and society', Journal of the Royal Society, 4.15: 707-19,

http://www.pubmedcentral.nih.gov/articlerender.fcgi?artid=2373389\&tool=pmcentrez\&rendertype =abstract (5 November 2012)

-(2007b) 'Deliberate futures: precaution and progress in social choice of sustainable technology', Sustainable Development 15.5: 286-295, http://doi.wiley.com/10.1002/sd.347 (5 November 2012)

-(2006) 'From Science and Society to Science in Society: Towards a Framework for "Co-operative Research"', Report of an European Commission Workshop, Luxembourg: Office for Official Publications of the European Communities

-(2006a) From Science and Society to Science in Society: towards a framework for co-operative research, Report, Brussels: European Commission 
-(2006b) 'Precaution, Foresight and Sustainability: reflection and reflexivity in the governance of science and technology' pp. 225-272 in J-P. Voss and R. Kemp (eds) Reflexive Governance for Sustainable Development, Cheltenham: Edward Elgar

-(2004) 'Opening Up or Closing Down? analysis, participation and power in the social appraisal of technology', Japan Journal for Science Technology and Society 14: 63-83

-(2003) 'Risk, Uncertainty and Precaution: Some Instrumental Implications from the Social Sciences' in F. Berkhout, M. Leach, and I. Scoones (eds) Negotiating Change: new perspectives from the social sciences, Cheltenham: Edward Elgar

-(ed.) (2001a) On Science and Precaution in the Management of Technological Risk - Volume II: Casestudies, Sevilla: Institute for Prospective Technological Studies

-(ed.) (2001b) On science and precaution in the management of technological risk : an ESTO project report, Sevilla: European Commission, Joint Research Centre

-(1999) 'Risk at a turning point?', Journal of Environmental Medicine 1.3: 119-126, http://dx.doi.org/10.1002/1099-1301(199907/09)1:3<119::AID-JEM20>3.0.CO;2-K

-(1998) On the Economics and Analysis of Diversity,SPRU Electronic Working Papers 28, Brighton: SPRU, University of Sussex

-(1997) 'Limits to the Value of External Costs', Energy Policy 25.5: 517-540, http://www.sciencedirect.com/science/article/pii/S0301421597000414

-(1994) 'Diversity and ignorance in electricity supply investment: Addressing the solution rather than the problem', Energy Policy 22.3: 195-216, http://www.sciencedirect.com/science/article/pii/0301421594901597

Stirling, A. and Gee, D. (2002) 'Science, precaution, and practice', Public Health Reports 117.6: 52133 ,

http://www.pubmedcentral.nih.gov/articlerender.fcgi?artid=1497477\&tool=pmcentrez\&rendertype =abstract

Stirling, A. and Mayer, S. (2001) 'A novel approach to the appraisal of technological risk: a multicriteria mapping study of a genetically modified crop' Environment and Planning C-Government and Policy 19.4: 529-555

Stirling, A. and Scoones, I. (2009) 'From Risk Assessment to Knowledge Mapping: Science, Precaution, and Participation in Disease Ecology', Ecology and Society, 14.4: 14

Stirling, A., Leach, M., Mehta, L., Scoones, I., Smith, A., Stagl, S. and Thompson, J. (2007) Empowering Designs: towards more progressive appraisal of sustainability, STEPS Working Paper 3, Brighton: STEPS Centre

Sudbury, J. (1998) Other Kinds of Dreams: black women's organisations and the politics of transformation, London: Routledge

Sundqvist, T., Stirling, A. and Soderholm, P. (2004) 'Electric power generation: valuation of environmental costs' pp. 229-243 in C. J. Cutler (ed.) Encyclopedia of Energy, Elsevier Science 
Sunstein, C.R. (2005) Laws of Fear: beyond the precautionary principle (The Seeley Lectures), Cambridge: Cambridge University Press

Suter, G.W. (2006) Ecological Risk Assessment, Abingdon: CRC Press

Swart, R., Bernstein, L., Minh, H-D. and Petersen, A. (2008) 'Agreeing to disagree: uncertainty management in assessing climate change, impacts and responses by the IPCC', Climatic Change 92.12: 1-29 http://link.springer.com/10.1007/s10584-008-9444-7 (31 July 2013)

Swierstra, T. and Rip, A. (2007) 'Nano-ethics as NEST-ethics: Patterns of Moral Argumentation About New and Emerging Science and Technology', NanoEthics 1.1: 3-20, http://www.springerlink.com/index/10.1007/s11569-007-0005-8 (3 November 2012)

Szoka, B. and Marcus, A. (eds) (2010) The Next Digital Decade: essays on the future of the internet, Washington DC: TechFreedom

Tait, J. (2009) 'Upstream engagement and the governance of science: the shadow of the genetically modified crops experience in Europe', EMBO Reports 10: S18-S22

Taleb, N. N. (2007) The Black Swan: The Impact of the Highly Improbable, New York: Random House

Taverne, D. (2005) The march of unreason: science, democracy, and the new fundamentalism, Oxford: Oxford University Press

Tenner, E. (1999) Why Things Bite Back: technology and the revenge of unintended consequences, New York: Vintage

Thompson, M. and Warburton, M. (1985) 'Decision Making Under Contradictory Certainties: how to save the Himalayas when you can't find what's wrong with them', Journal of Applied Systems Analysis 12: $3-34$

Thornton, J (2000) Pandora's Poison: chlorine, health and a new environment strategy, Cambridge MA: MIT Press

Tickner, J. A. and Wright, S. (2003) 'The precautionary principle and democratizing expertise : a US perspective', Science and Public Policy 30.3: 213-218

Tornatzky, L. G., Fergus, E. O., Avellar, J. W., Fairweather, G. W. and Fleischer, M. (1980) Innovation and Social Process: national experiment in implementing social technology, New York: Pergamon

TSB (2011) Concept to Commercialisation: A strategy for business innovation, 2011-2015, London: Technology Strategy Board

UNEP (1992) Rio Declaration on Environment and Development, Rio de Janeiro: UNEP

Unruh, G. C. (2002) 'Escaping carbon lock-in', Energy Policy 30.4: 317-325, http://linkinghub.elsevier.com/retrieve/pii/S0301421501000982

-(2000) 'Understanding carbon lock-in', Energy Policy 28: 817-830

Uphoff, N. (ed.) (2002) Agroecological Innovations: increasing food productivity with participatory development, London: Earthscan 
Van Asselt, M. A. and Rotmans, J. (2002) 'Uncertainty in Integrated Assessment Modelling: From Positivism to Pluralism', Climatic Change 54: 75-105

Von Hippel, E. (2005) Democratizing Innovation, Cambridge MA: MIT Press

Voss, J., Bauknecht, D. and Kemp, R. (eds) (2006) Reflexive Governance for Sustainable Development, Cheltenham: Edward Elgar

Wagner, M. (2003) The Porter Hypothesis Revisited: A Literature Review of Theoretical Models and Empirical Tests, Lueneberg: Centre for Sustainability Management

Walker, W. (2000) 'Entrapment in large technology systems: institutional commitment and power relations', Research Policy 29.7-8: 833-846,

http://linkinghub.elsevier.com/retrieve/pii/S0048733300001086

Warren-Hicks, W. J. and Hart, A. (eds) (2010) Application of Uncertainty Analysis to Ecological Risks of Pesticides, Pensecola: SETAC Press

Watts, S. (2014) 'Genetic moderation is needed to debate our food future', New Scientist 2979 (July): $8-10$

WBCSD (2010) Vision 2050, Geneva: World Business Council for Sustainable Development

WBGU (2004) World in Transition Towards Sustainable Energy Systems, Berlin: German Federal Council on Global Change

Weitzman, M. L. (1992) 'On Diversity', Quarterly Journal of Economics 107.2: 363-405

WHO, 2013. Health and environment: communicating the risks, Copenhagen.

-(1999) Removing Obstacles to Healthy Development, Geneva: World Health Organization

-(2002) The 10 / 90 Report on Health Research, Geneva: World Health Organization

Wilsdon, J., Willis, R. (2004) See-through science : why public engagement needs to move upstream, London: Demos, http://www.demos.co.uk/files/Seethroughsciencefinal.pdf

Wilsdon, J., Wynne, B. and Stilgoe, J. (2005) The Public Value of Science: or how to ensure that science really matters, London: Demos

Winner, L. (1977) Autonomous Technology: technics out of control as a theme in political thought, Camb MA: MIT Press

-(ed.) (1992) Democracy in a Technological Society, Dordrecht: Springer

Wolpert, L. (1992) The Unnatural Nature of Science: wy science does (not) make common sense, London: Faber and Faber

Wright, O. (2013) 'Opponents of third world GM crops are "wicked", says Environment Secretary Owen', The Guardian, 14 October 2013: 1-10

WWF (2011) The Energy Report: 100\% renewable energy by 2050, Gland: World Wildlife Fund 
Wyatt, S., Henwood, F., Miller, N. and Senker, P. (eds) (2000) Technology and In/equality: questioning the information society, London and New York: Routledge

Wynne, B. (2006) 'Public engagement as a means of restoring public trust in science-Hitting the notes, but missing the music? Community Genetics 9: 211-220

Wynne, B. (2007) 'Public Participation in Science and Technology: Performing and Obscuring a Political-Conceptual Category Mistake', East Asian Science, Technology and Society: an International Journal 1.1: 99-110, http://www.springerlink.com/index/10.1007/s12280-007-9004-7 (3 November 2012)

Wynne, B. (2002) 'Risk and Environment as Legitimatory Discourses of Technology: Reflexivity Inside Out?', Current Sociology, 50.3: 459-477

Wynne, B. (1992) 'Uncertainty and Environmental Learning: reconceiving science and policy in the preventive paradigm', Global Environment Change 2.2: 111-127

Yanarella, E. J. (2002) The Missile Defence Controversy: technology in search of a mission, Lexington: University Press of Kentucky

Yoshizawa, G., Stirling, A. and Suzuki, T. (2011) 'Multicriteria Diversity Analysis: theory, method and an illustrative application', pp. 211-243 in A. Markandya, I. Galarraga, M. Gonzalez-Eguino (eds) Handbook on Sustainable Use of Energy, Cheltenham: Edward Elgar

Van Zwanenberg, P. and Millstone, E. (2000) "Mad cow disease' 1980s-2000: how reassurance undermined precaution' in P.Harremoës, D. Gee, M. MacGarvin, A. Stirling, J. Keys, B. Wynne and S. Guedes Vaz (eds) Late lessons from early warnings: the precautionary principle 1896-2000, Environment Issue Report 22, Copenhagen: European Environment Agency 